Georgetown University Law Center

Scholarship @ GEORGETOWN LAW

1993

\title{
Prospective Overruling and the Revival of 'Unconstitutional' Statutes
}

William Michael Treanor

Georgetown University Law Center, wtreanor@law.georgetown.edu

Gene B. Sperling

National Economic Council

This paper can be downloaded free of charge from:

https://scholarship.law.georgetown.edu/facpub/1063

93 Colum. L. Rev. 1902-1955 (1993)

This open-access article is brought to you by the Georgetown Law Library. Posted with permission of the author. Follow this and additional works at: https://scholarship.law.georgetown.edu/facpub

Part of the Constitutional Law Commons, Courts Commons, Judges Commons, Legal History Commons, and the Legislation Commons 


\title{
PROSPECTIVE OVERRULING AND THE REVIVAL OF "UNCONSTITUTIONAL" STATUTES
}

\author{
William Michael Treanor* \\ and Gene B. Sperling**
}

\section{INTRODUCTION}

The Supreme Court's decision in Planned Parenthood v. Casey ${ }^{1}$ reshaped the law of abortion in this country. The Court overturned two of its previous decisions invalidating state restrictions on abortions, Thornburgh v. American College of Obstetricians and Gynecologists ${ }^{2}$ and Akron v. Akron Center for Reproductive Health, ${ }^{3}$ and it abandoned the trimester analytic framework established in Roe v. Wade ${ }^{4}$ At the time Casey was handed down, twenty states had restrictive abortion statutes on the books that were in conflict with Akron or Thornburgh and which were unenforced. ${ }^{5}$ In six of these states, courts had held the statutes uncon-

* Associate Professor of Law, Fordham University; B.A., Yale College, 1979; A.M., Harvard University, 1982; J.D., Yale Law School, 1985.

** Deputy Assistant to the President for Economic Policy; B.A., University of Minnesota, 1981; J.D., Yale Law School, 1985.

The authors began this article as a result of their discussions about Weeks $v$. Connick, 733 F. Supp. 1036 (E.D. La. 1990), discussed infra at text accompanying notes 9-14. In that case, Mr. Sperling was co-counsel on the amicus brief filed by the National Abortion Rights Action League (NARAL). The authors would like to thank the following people for their comments and suggestions: Akhil Amar, Vikram Amar, Marc Arkin, Evan Caminker, Claudia Center, George Cochran, Jill Fisch, Martin Flaherty, James Fleming, Michael Gerhardt, Charles Goetz, Tracy Higgins, Dawn Johnsen, Robert Kaczorowski, James Kainen, Gerard Lynch, Michael Martin, Russell Pearce, James Robertson, Howard Shapiro, Steven Shiffrin, Reva Siegel, Steven Thel, Georgene Vairo, and Marcy Wilder. An earlier version of this paper was presented at a Fordham faculty colloquium, and the authors would also like to thank the participants in that colloquium for their valuable insights. Fordham Law School provided generous financial assistance to Mr. Treanor. Jennifer Ross, Alexis Schatten, and Wendy Stynes supplied superb research support. Finally, Mr. Sperling wishes to thank Mr. Treanor for completing the drafting of the article and for revising the article (including adding the argument that the remedy for the revival problem is extension of prospective overruling to the statutory context) after Mr. Sperling joined the Clinton campaign and administration.

1. 112 S. Ct. 2791 (1992).

2. 476 U.S. 747 (1986). For that part of Casey overturning Thornburgh's finding of a constitutional violation when a government regulation requires the provision of information that is truthful but aimed at convincing women not to have abortions, see Casey, 112 S. Ct. at 2823 (plurality opinion).

3. 462 U.S. 416 (1983) (Akron I). The Supreme Court in Akron I held unconstitutional a mandatory 24-hour waiting period and a requirement that women considering abortion be provided with information that, while truthful, was designed to dissuade them from having an abortion. Casey overturned these holdings. See Casey, 112 S. Ct. at 2822-26 (plurality opinion).

4. 410 U.S. 113 (1973). For the relevant part of Casey, see 112 S. Ct. at 2818 (plurality opinion) (rejecting Roe's trimester framework).

5. The following is a list of the relevant statutory or regulatory provisions that 
stitutional. ${ }^{6}$ Almost as soon as the Casey ruling was announced, the campaign to secure enforcement of these restrictions began. ${ }^{7}$

Are these statutes good law, despite the fact that they were once in conflict with governing Supreme Court precedent (and in some cases had been judicially determined to violate women's constitutional rights)? Alternatively, will they have to be re-enacted by the legislature to be enforceable? These questions highlight the revival issue. The revival issue arises when a court overrules a prior decision in which it had held a statute unconstitutional. (We will throughout this article refer to the first decision as the "invalidating decision," and to the second decision as the "overruling decision.") Should the enforceability of a statute passed prior to the overruling decision be determined by reference to the invalidating decision-in which case the statute would have to be repassed to be in effect-or by reference to the overruling decision-in which case the statute would not have to be repassed? In other words, does the overruling decision automatically revive a previously unenforceable statute?

established waiting periods and/or counseling requirements that were inconsistent with the Court's holding in Akron I and Thornburgh: Ala. Admin. Code r. 420-5-.03 (Supp. 1990); Del. Code Ann. tit. 24, § 1794 (1987); Idaho Code § 18-609 (1987); Ind. Admin. Code tit. 410, r. 3.5-1 to 3.5-4 (1992); Ky. Rev. Stat. Ann. §§ 311.726, .729 (Michie/ Bobbs-Merrill 1990); La. Rev. Stat. Ann. § 40:1299.35.6 (West 1992); Me. Rev. Stat. Ann. tit. 22, § 1599 (West 1992); Mass. Gen. Laws Ann. ch. 112, § $12 S$ (West 1990 \& Supp. 1992); Miss. Code Ann. §§ 41-41-33, -35 (Supp. 1990); Mo. Ann. Stat. § 188.039 (Vernon 1983 \& Supp. 1992); Mont. Code Ann. § 50-20-104(3), -106 (1991); Neb. Rev. Stat. §§ 28-326(8), -327 (1989); N.D. Cent. Code § 14.02.1-03 (1991); Ohio Rev. Code Ann. § 2317.56 (Baldwin Supp. 1992); 18 Pa. Cons. Stat. Ann. § 3205 (Supp. 1991); R.I. Gen. Laws §§ 23-4.7-2 to -5 (1989); S.D. Codified Laws Ann. §§ 34-23A (Michie 1987 \& Supp. 1993); Tenn. Code Ann. § 39-15-202 (1991 \& Supp. 1992); Utah Code Ann. §§ 76-7-305, -305.5 (1990 \& Supp. 1993); Wis. Stat. Ann. § 46.245 (West 1987), $\S 146.78(1)$, (2) (West 1989 \& Supp. 1990); Wis. Admin. Code $\S[$ Med] 11.04 (May 1989). On the absence of enforcement of these statutes, see National Abortion Rights Action League, Who Decides? A State-by-State Review of Abortion Rights (4th ed. 1993) [hereinafter 1993 NARAL] (analyzing status of state abortion regulations).

6. See Eubanks v. Brown, 604 F. Supp. 141 (W.D. Ky. 1984) (Kentucky statute); Margaret S. v. Treen, 597 F. Supp. 636 (E.D. La. 1984) (Louisiana statute), aff'd, 794 F.2d 994 (5th Cir. 1986); Women's Community Health Ctr. v. Tierney, Civ. No. 79-162P (D. Me. Sept. 9, 1983) (Maine statute); Planned Parenthood v. Bellotti, 641 F.2d 1006 (1st Cir. 1981) (Massachusetts statute); Barnes v. Moore, No. J86-9458(W) (S.D. Miss. Aug. 30, 1991) (Mississippi statute), rev'd, 970 F.2d 12 (5th Cir.), cert. denied, 113 S. Ct. 656 (1992) (reversal based on Casey); Preterm Cleveland v. Voinovich, No. 92CVH01-528 (Ohio Ct. C. P., Franklin County, May 27, 1992), rev'd, 1993 WL 303631 (Ohio Ct. App., July 27, 1993) (Ohio statute) (reversing lower court's grant of injunctive relief barring operation of the Ohio statute and holding the statute constitutional in light of Casey).

7. See Letter from Eric I. Miller, Esq., Miller and Waters, Attorneys and Counselors at Law, to John C. Bailey, M.D., State Health Commissioner, Indiana State Board of Health (June 29, 1992) (seeking enforcement of Indiana informed consent law in light of Casey) (on file with authors); see also Barnes v. Moore, 970 F.2d 12, 13-14 (5th Cir. 1992) (reversing lower court injunction against enforcement of Mississippi statute in light of Casey). 
The way in which the revival issue is resolved will thus determine whether, in light of Casey, previously unenforced statutes became enforceable without the need for any post-Casey legislative action. In addition to affecting what kind of abortion regulations are in effect in twenty states in the immediate wake of Casey, this determination has profound consequences for the kind of abortion regulations that will be in effect in these states in the future. Such long-term consequences reflect the fact that our governmental system is not one of pure majoritarianism and that the burden of inertia in our legislative process is heavy: as we will discuss, statutes on the books can stay on the books even if a current majority no longer desires them; in contrast, proposed statutes need supermajoritarian support to secure passage. ${ }^{8}$ Therefore, the starting point for future legislative action-such as whether pre-Casey abortion regulations are enforceable-influences the legislative action that in fact develops.

The revival issue arose in perhaps its starkest form in the case of Weeks v. Connick. ${ }^{9}$ In 1989, elected officials in Louisiana responded to the Supreme Court's decision in Webster $v$. Reproductive Health Services 10 by claiming that $R o e$ had been effectively overruled and by seeking enforcement of a draconian 134-year-old law criminalizing abortion ${ }^{11}$ which had previously been found unconstitutional under Roe. ${ }^{12}$ The court in Weeks avoided confronting the revival issue by holding that the statute in question had been implicitly repealed. ${ }^{13}$ As the Court's decision in Casey made clear, Webster did not overrule Roe, and the Court is unlikely to allow the enforcement of criminal abortion laws in the near future. But Louisiana's attempt to enforce its $\mathbf{1 8 5 5}$ statute focused significant attention for the first time on the future status of the dozens of then-unconstitutional state abortion restrictions, as well as on the revival issue more generally. ${ }^{14}$

8. For further discussion, see infra Part III.A.

9. 733 F. Supp. 1036 (E.D. La. 1990).

10. 492 U.S. 490 (1989).

11. The statute prohibited all abortions and provided that doctors who performed abortions would receive a minimum sentence of one year at hard labor and a maximum sentence of ten years at hard labor. See La. Rev. Stat. Ann. $§ 14: 87,: 87.4,: 88$ (West 1986).

12. See Weeks, 733 F. Supp. at 1037.

13. After the criminal abortion statute was enjoined in 1976, the Louisiana legislature passed a series of statutes regulating abortion. The court held that, by thus opting for the path of regulation rather than criminalization in these statutes, the Louisiana legislature implicitly repealed the earlier statute. See id. at 1037-38. After Weeks, the state legislature amended and narrowed this criminal abortion statute. See La. Rev. Stat. Ann. § 14:87 (West 1993). See also Sojourner v. Roemer, 772 F. Supp. 930 (E.D. La. 1991) (holding statute unconstitutional and granting injunction against enforcement), aff'd, 974 F.2d 27 (5th Cir. 1992), cert. denied, 113 S. Ct. 1414 (1993). The amended statute is discussed at note 113 , infra.

14. For examples of press coverage of this story, see Louisiana: Back to the "Dark Ages"?, Newsweek, Oct. 9, 1989, at 34; Frances Marcus, Louisiana Lawyers Move to 
While the Court's recent abortion decisions dramatically illustrate the consequences that may follow when a court, after having held a statute unconstitutional, overrules that decision, the revival issue is certainly not limited to the abortion context. Indeed, it is one that will likely arise with growing frequency in the coming years, for the Supreme Court has been closely divided recently on a wide range of constitutional matters. In his 1991 dissent in Payne $v$. Tennessee, ${ }^{15}$ Justice Marshall listed seventeen important constitutional cases decided since 1985 by a vote of five to four. ${ }^{16}$ Given the Supreme Court's current state of ideological flux, Justice Ginsburg's recent appointment, and the likelihood of additional Supreme Court vacancies in the next few years, there may well be reversals of determinations of unconstitutionality involving affirmative action, ${ }^{17}$ the Establishment Clause, ${ }^{18}$ free speech, ${ }^{19}$ and governmental takings of private property. ${ }^{20}$ Increasing the likelihood of such reversals is the overall tendency by the Court in recent years to accord diminished weight to the principle of stare decisis. $^{21}$

In this Article, we argue that in some-but not all-circumstances,

Revive Invalidated Laws Banning Abortions, N.Y. Times, Oct. 7, 1989, at A9; Ruth Marcus, State Pleads to Reimpose Criminal Abortion Law, Wash. Post, Oct. 7, 1989, at A7.

15. 111 S. Ct. 2597, 2619-25 (1991) (Marshall, J., dissenting).

16. See id. at 2623 n.2 (Marshall, J., dissenting).

17. See Wygandt v. Jackson Bd. of Educ., 476 U.S. 267, 279-84 (1986) (layoff provision that favored minority teachers found to violate Equal Protection Clause) (five vote majority opinion).

18. See Aguilar v. Felton, 473 U.S. 402, 408-14 (1985) (Establishment Clause found to bar governmental financial assistance to parochial schools) (five vote majority).

19. See Rutan v. Republican Party, 497 U.S. 62, 74-76 (1990) (First Amendment right not to be denied public employment or pay increase within public employment because of party affiliation) (five vote majority); Peel v. Attorney Registration and Disciplinary Comm'n, 496 U.S. 91, 110-11 (1990) (attorney found to have First Amendment right to advertise legal specialization) (five vote majority); Rankin v. McPherson, 483 U.S. 378, 384-92 (1987) (First Amendment right of public employee to express views on matters of public importance) (five vote majority).

20. See Lucas v. South Carolina Coastal Council, 112 S. Ct. 2886, 2888 (1992) (governmental regulation that deprives property of all value is a taking unless regulation reflects restrictions present in the background principles of the state's law of property and nuisance) (five vote majority).

21. See generally Michael Gerhardt, The Role of Precedent in Constitutional Decisionmaking and Theory, 60 Geo. Wash. L. Rev. 68 (1991). For example, according to Professor Gerhardt's study, of the 105 cases in which the Court has overturned prior decisions, 64 were handed down from 1960 to the present. See id. at 147-59 (listing cases). There are, of course, exceptions to this general trend, and Casey reflects a greater respect for precedent than had been commonly anticipated. See generally Kathleen M. Sullivan, The Supreme Court, 1991 Term-Foreword: The Justices of Rules and Standards, 106 Harv. L. Rev. 22, 27-40 (1992) (discussing Casey and Lee v. Weisman, 112 S. Ct. 2649 (1992), as instances of "surprising moderation" which reflected presumption that precedent should be followed in the absence of compelling reasons to the contrary). 
statutes that were unconstitutional under the rule enunciated in the invalidating decision should not be revived when the invalidating decision is overturned. We base this conclusion upon two separate and independent theoretical bases.

First, full examination of the revival issue demonstrates the interactive nature of the relationship between judicial invalidation of statutes and majoritarian decision-making. Judicial review is not purely external to the legislative process: the very act of judicial invalidation powerfully shapes subsequent legislative deliberations. Belief in the finality of judicial judgments is so pervasive that, when a statute is struck down or when a judicial decision establishes a rule of law under which a statute is unconstitutional, its opponents frequently act as if the statute were gone for all time. At the very least, even if political actors realize the potential for reversal, the finding of unconstitutionality alters the way in which they spend their political capital. As a result, rather than seek to repeal a statute that appears to be, for all practical purposes, a nullity, they devote their political resources to other-more clearly consequential-matters. Revival in such circumstances can produce a result contrary to what the political process would have produced in the absence of the initial judicial decision.

We will call the response of political actors to judicial decisions political reliance. Proper concern for the majoritarian process leads to the conclusion that in some situations political reliance merits protection through nonrevival.

Second, the revival issue dramatically raises the question: when should statutes adopted by past majorities establish the starting point for current majoritarian lawmaking? The revival issue thus forces reconsideration of a question that has troubled Americans since the times of the debates over the ratification of the Constitution: why should we defer to what past majorities decided rather than consider issues anew? In this Article, we argue that, given the essentially libertarian bias of our constitutional system of governance, a statute that has once been unconstitutional under governing case law should not be revived if it constrains individual liberty (as do, for example, the abortion regulations sanctioned by Casey).

The way to protect political reliance and to force legislative reconsideration of constitutionally problematic statutes is through an extension of the doctrine of prospective overruling. When a court prospectively overrules an earlier decision, it decides that the new rule of law - the law announced in the overruling decision-will be applied only in cases that arise in the future; other cases will continue to be decided under the rule of law enunciated in the decision that is being overruled. The doctrine of prospective overruling currently applies only to conduct engaged in prior to the overruling decision. Recognition of the existence and the importance of political reliance and of the importance of legislative reconsideration of constitutionally problem- 
atic statutes warrants an expansion of this technique. In this Article, we will argue that in a limited class of cases the doctrine of prospective overruling should be available to courts as they consider the enforceability of statutes enacted prior to the overruling decision. Thus, in certain instances, the overruling decision would not lead to revival; rather, a court would apply the rule of law of the initial decision to statutes passed prior to the overruling decision and therefore bar enforcement of the statutes (unless they were repassed after the overruling decision).

This argument for the extension of prospective overruling is novel, and the argument that the overruling decision need not always mean automatic revival runs counter to the weight of judicial and scholarly opinion on point. The Supreme Court has-without analysis of the issue-revived previously unenforceable statutes. A limited number of state courts and commentators have explicitly addressed the issue and have concluded almost uniformly that a statute barred under the invalidating decision becomes enforceable when that decision is overturned. There is, however, no controlling federal case law in which the revival issue is addressed, and so, with respect to federal law and the law of most states, the revival issue remains open. In Part I, as a prelude to our argument, we set out this relevant case law and scholarly work.

Part II elaborates on the first of the two previously discussed theoretical bases for the argument against revival. Here, we develop the political reliance argument for prospective overruling in the statutory context and outline when political reliance makes prospective overruling appropriate. This part discusses what political reliance is and offers specific historical examples in which political actors have shaped their decisions in reliance on judicial decisions. It then compares political reliance to other types of reliance interests that the law safeguards through the use of stare decisis, qualified immunity for government officials in tort suits, and prospective overruling.

We argue that, just as Benjamin Cardozo created the doctrine of prospective overruling to protect individuals who structured transactions in reliance on judicial decisions, so it is now appropriate to extend the doctrine of prospective overruling to the statutory context to protect political decision-making. We see prospective overruling in the statutory context as an exercise of the judicial power to construct a remedy to protect those who have relied on earlier judicial pronouncements. Use of this technique would be discretionary and situationspecific, and we discuss in what types of cases it would be appropriate to use prospective overruling to protect political reliance. Specifically, we contend that in determining whether there has been political reliance and whether such reliance merits protection, courts should consider the amount of time that elapsed between the invalidating decision and the overruling decision, whether the statute at issue was clearly unconstitutional under the invalidating decision, and whether the statute was passed before or after the invalidating decision. 
Part III develops the second of our two arguments against revival, focusing on the question of when current majorities should be forced to revisit previously passed statutes. In addition to advancing a theoretical basis for prospective overruling of statutes separate from that developed in Part II, this part defines a separate category of cases in which use of the technique is appropriate. We draw here on Alexander Bickel's argument in his essay "The Passive Virtues"22 that courts should use a variety of technical devices to force current legislative reconsideration of constitutionally troublesome statutes. Consideration of Bickel's essay and its implications suggests that use of the doctrine of prospective overruling is particularly appropriate when the statute in question implicates individual liberty interests. The technique of prospective overruling should be used to ensure that, when an invalidating decision is concerned with the protection of individual liberty, a statute that was unconstitutional under the rule of law set forth in that decision is not revived by the overruling decision. Such a statute should be enforceable only if it is desired by a current majority, and the measure of whether it is desired by a current majority is whether it is repassed following the overruling decision.

\section{Cases and Writings on Revival}

While the great majority of relevant judicial opinions and scholarly writings favors revival, it is striking how little consideration the issue has received and how little case law has explicitly addressed the topic. Typically, it has simply been assumed, without recognition of the attendant problems, that if a statute is constitutional under the rule established in the overruling decision it should be enforceable without the need for repassage. When the revival issue has been analyzed, the analysis has generally been both cursory and highly formalistic. This part surveys the case law and previous writings bearing on revival, beginning with Supreme Court decisions and then turning to state court opinions and the scholarly literature.

\section{A. Supreme Court Case Law}

The Supreme Court has not authoritatively addressed the issue of whether the enforceability of a statute passed prior to the announcement of the overruling decision should be judged by the rule of law enunciated in the invalidating decision or by the rule of law enunciated in the overruling decision. Nonetheless, in several cases it has simply applied the rule of law of the overruling decision to such statutes, adopting an approach in accordance with the general principle that a new rule of constitutional law applies retroactively. ${ }^{23}$ Thus, it is true

\footnotetext{
$؛ \rightarrow$ Alexander M. Bickel, The Supreme Court, 1960 Term-Foreword: The Passive Virtues, 75 Harv. L. Rev. 40 (1961).

23. It should be added at the outset that there are exceptions to this general
} 
both that revival has been the Supreme Court's practice and that the Court has not resolved the revival issue.

The principle that new rules of law normally apply retroactively has considerable antiquity. The relevant Supreme Court precedent can be traced back to the 1801 decision in United States v. Schooner Peggy. ${ }^{24}$ Schooner Peggy involved a condemnation proceeding for a French ship seized pursuant to presidential authorization. While the case was before the Court, a treaty with France was ratified which provided that property that had been seized but not definitively condemned had to be returned to its owners. The Court therefore faced the question whether the treaty governed the case, even though ratification followed issuance of decisions by the district court and circuit court. Chief Justice Marshall held the treaty applicable, stating if "a law . . positively changes the rule which governs, the law must be obeyed."25 While Schooner Peggy concerned the retroactive effect of a treaty, the doctrine that a change in law applies retroactively was later extended beyond this context. Thus, the Supreme Court in 1969 observed that a new rule of law applies retroactively, regardless of whether the basis of the change in law is "constitutional, statutory, judicial [, or even] where the change is made by an administrative agency acting pursuant to legislative authorization." 26

This principle of retroactive application of new law has been applied by the Court when it evaluates the constitutionality and enforceability of statutes passed prior to the announcement of a new rule of constitutional law. Indeed, the Court seems not to have even considered that in this context special circumstances might warrant the prospective application of a new rule of law. Casey illustrates this point. At the time of its passage, the Pennsylvania statute at issue in the case was, according to the holdings in Akron and Thornburgh, unconstitutional. ${ }^{27}$ Yet, having decided to overrule these precedents, the Court simply ap-

principle. In particular, as will be discussed in Part II, infra, prospective overruling is an exception to that principle.

24. 5 U.S. (1 Cranch) 103 (1801).

25. Id. at 110 .

26. Thorpe v. Housing Auth., 393 U.S. 268, 282 (1969). In Thorpe, the Court ruled that the Schooner Peggy doctrine applied to intervening agency decisions. Five years later, however, the Court retreated from applying the Schooner Peggy doctrine in this context. See NLRB v. Food Store Employees Union, Local 347, 417 U.S. 1, 10 \& n.10 (1974) (remanding for agency determination the decision as to whether a new policy should apply retroactively). On the ambit of the Schooner Peggy doctrine, see John B. Corr, Retroactivity: A Study in Supreme Court Doctrine "as Applied," 61 N.C. L. Rev. 745, 756-57 (1983) (discussing the Schooner Peggy doctrine and its relationship to conflicting criminal law doctrines); Walter V. Schaefer, Prospective Rulings: Two Perspectives, 1982 Sup. Ct. Rev. 1, 19-21.

27. See Planned Parenthood v. Casey, 112 S. Ct. 2791, 2822-26 (1992) (plurality opinion) (overruling the decisions in Akron $I$ and Thomburgh that found informed consent requirements to be unconstitutional and also overruling tkron I's ban on waiting periods). 
plied its new rule of law to the challenged statute. The Court did not consider whether it would have been more appropriate to judge the statute's constitutionality or its enforceability under the case law that governed at the time of its passage or that had governed during its existence prior to the Court's decision in Casey. ${ }^{28}$

West Coast Hotel v. Parrish ${ }^{29}$ also illustrates the point. In Adkins v. Children's Hospital ${ }^{30}$ - the decision overturned in West Coast Hotel the Court had found that the District of Columbia statute establishing a minimum wage for children and women violated liberty of contract. In West Coast Hotel, the Court considered a substantially similar Washington State statute establishing a minimum wage for women. The Court overruled Adkins and, without analysis, simply applied its new rule of law to uphold the Washington State statute. ${ }^{31}$

Neither Casey nor West Coast Hotel concerned the same statute that had been the subject of the invalidating decision. The Legal Tender Cases ${ }^{32}$ however, represent the application of a statute in a context in which the Court had previously held that the statute could not constitutionally be applied. In Hepburn v. Griswold ${ }^{33}$ the Supreme Court in 1870 held that the Legal Tender Act of $1862^{34}$-which provided that federally issued notes could be used to pay off any debt-could not constitutionally be applied to obligations entered into before its passage. ${ }^{35}$ Less than two years later, with the appointment of two new

28. See id. It should be added that, on remand, the district court has ruled that the Supreme Court's decision in Casey did not ultimately resolve the question of the constitutionality of the Pennsylvania statute. According to the district court, the Supreme Court found only that certain portions of the statute were constitutional on the record before it, and the district court directed that the record be supplemented in order to determine whether, on a fuller record, the statute would still satisfy the undue burden test of the Casey plurality. See Planned Parenthood v. Casey, 822 F. Supp. 227, 233 (E.D. Pa. 1993).

29. 300 U.S. 379 (1937).

30. 261 U.S. 525 (1923), overruled by L'est Coast Hotel, 300 U.S. 379.

31. See West Coast Hotel, 300 U.S. at 400 . It should be added that the Washington State statute, originally passed in 1913, had been continuously enforced since its enactment, despite the Court's ruling in 1923 in Adkins and despite the fact that there was no material difference between the District of Columbia statute overturned in Adkins and the Washington state statute. See id. at 388-91. Thus, West Coast Hotel is not a case in which the Court permitted enforcement of an unenforced statute. It is, however, a case in which a statute's constitutionality was determined by the rule of law enunciated in the overturning case, rather than the rule of law in the overturned case.

32. 79 U.S. (12 Wall.) 457 (1870).

33. 75 U.S. (8 Wall.) 603 (1868).

34. 12 Stat. 345,532 .

35. The case was decided by a vote of five to three, and the five vote majority was split as to its rationale. Four Justices held that the statute covered preexisting obligations and that in so doing it violated the Legal Tender Clause. Justice Grier, the fifth vote for the majority, took the position that the statute did not cover preexisting debts, but that if it did, it was unconstitutional. See Hepburn, 75 U.S. at 626 . (Justice Grier did not file a separate opinion. He voted on the case in conference, but resigned from the Court between the time when the decision was scheduled to be read and when 
Justices to the Court, the Court reversed itself, specifically overruled Hepburn, and found the Act constitutional as to both preexisting and subsequent obligations. ${ }^{36}$ In justifying the reversal, the majority in the Legal Tender Cases noted that there was a vacancy on the Court at the time that Hepburm was decided and that constitutional issues should not be resolved "in the absence of a full Court, if it can be avoided." 37 The Court also stated that, while overruling "should not be done inconsiderately, . . . in a case of such far-reaching consequences as the present, thoroughly convinced as we are that Congress has not transgressed its powers, we regard [overruling] as our duty." 38 In contrast to this concern with overruling precedent, there was no analysis at all of whether the statute should have to be repassed by Congress in order to be enforceable. The Court treated it as clear that repassage was not necessary. ${ }^{39}$

Supreme Court case law thus weighs in favor of revival; in a variety of circumstances, the Court has found that statutes that were inconsistent with a previous decision automatically became enforceable when that decision was reversed. This does not, however, imply active consideration of the revival issue. Indeed, in In re Rahrer, ${ }^{40}$ when one of the parties advanced the claim that a statute functionally identical to one held unconstitutional by the Court could be enforceable only if it were repassed after the Court had reversed its initial determination of unconstitutionality, the Court made clear that it was not resolving that

it was ultimately read. His position was summarized in the opinion of the Court. See id.) The three dissenters took the position that the statute applied to preexisting debts, and that it could constitutionally do so. See id. at 637-38 (Miller, J., dissenting).

36. See Legal Tender Cases, 79 U.S. at 553.

37. Id. at 554 .

38. Id.

39. With respect to the Legal Tender Cases, we are not arguing that, under our approach, Congress would have had to re-enact the Legal Tender Act after the overruling decision in order for it to apply to preexisting debts. In Part II we contend that there are a variety of factors that courts should employ in deciding whether there has been political reliance and hence whether requiring re-enactment would be appropriate. One factor is the extent to which it was clear that the invalidating decision applied to the statute at issue in the subsequent case. See infra Part II.D. Thus, when the invalidating decision actually concerned the statute later at issue, as in Hepburn, political reliance is to be expected in the ordinary course of events. However, since the Hepburn decision provoked immediate controversy and was judicially reconsidered and rejected within a brief period of time, the argument that the Legal Tender Act was not repealed because of political reliance is weak. See discussion infra notes 143-145 and accompanying text. For further discussion of the history of the Legal Tender Cases, see 6 Charles Fairman, History of the Supreme Court of the United States, Reconstruction and Reunion 186488, Part I, at 677-775 (1971); Kenneth W. Dam, The Legal Tender Cases, 1981 Sup. Ct. Rev. $31 \rightarrow$ Charles Fairman, Mr. Justice Bradley's Appointment to the Supreme Court and the Legal Tender Cases (installment 1), 54 Harv. L. Rev. 977 (1941) [hereinafter Fairman, Legal Tender Cases].

40. 140 U.S. 545 (1891). 
issue. ${ }^{41}$ In those cases in which an unenforceable statute became enforceable, revival seems to have occurred because the Court assumed that it was a logical consequence of reversal, rather than because the Court considered the arguments against revival and rejected them.

\section{B. State Courts}

Unlike the Supreme Court, several state courts have explicitly addressed the revival issue. The relevant state court cases have concerned the specific issue of whether a statute that has been held unconstitutional is revived when the invalidating decision is overturned. ${ }^{42}$ With one exception, they have concluded that such statutes are immediately enforceable.

The most noted instance in which the revival issue was resolved by a court involved the District of Columbia minimum wage statute pronounced unconstitutional in Adkins. After the Court reversed Adkins in West Coast Hotel, President Roosevelt asked Attorney General Homer

41. See id. at 550-52 (argument of appellee); id. at 559-65 (opinion of the Court). Rahrer was prosecuted under a Kansas statute that barred selling any liquor in the state. In Leisy v. Hardin, 135 U.S. 100 (1890), the Court had held that a similar Iowa statute violated the Commerce Clause because it extended to liquor in interstate commerce. The rationale in Leisy was that states could regulate the sale of liquor in interstate commerce only with congressional approval, and that Congress had not approved such regulation. See Leisy, 135 U.S. at 119-25. After Leisy, Congress passed the Wilson Act, ch. 728, 26 Stat. 313 (1890) (codified at 27 U.S.C. $\$ 121$ (1988)), which permitted states to ban the sale of all liquor. Rahrer's attorneys argued that the decision in Leisy had rendered the Kansas Act a nullity, and that it would have been enforceable only if the state had repassed it after Congress had enacted the Wilson Act. See Rahrer, 140 U.S. at 550-52. The Court, however, found this argument inaccurately described Leisy. It stated that the Kansas law and similar statutes were never "absolutely void, in whole or in part $\ldots$ as if they had never been enacted. On the contrary, [Leisy] did not annul the law, but limited its operation to property strictly within the jurisdiction of the State." Id. at 563. In support of his argument that precedent supported revival, Professor Nimmer invoked the result in Rahrer. He minimized the significance and logical force of the language just quoted, writing, "Notwithstanding this disclaimer, it is difficult to avoid the conclusion that under Leisy, prior to the Wilson Act the Kansas statute was regarded as void in part,' i.e., in its application to interstate commerce in liquo $\rightarrow$ Melville B. Nimmer, A Proposal for Judicial Validation of a Previously Unconstitutional Law: The Civil Rights Act of 1875, 65 Colum. L. Rev. 1394, 1418 n.102 (1965). Nimmer's attack on the coherency of the Court's reasoning in Rahrer is telling. But the more important point for our argument is that the Court avoided confronting the revival issue directly. The result in Rahrer was that a statute that was once judicially barred from enforcement became enforceable. Nonetheless, the "disclaimer" had the effect of allowing the Court to avoid explicitly adopting the revival principle.

42. This issue is a subset of the revival issue. The revival issue is concerned, not simply with statutes that have been held to be unconstitutional, but with statutes that were never actually declared unconstitutional but that were at odds with the rule of law in the invalidating decision. As Casey and I'est Coast Hotel suggest, revival in the latter category of cases has been automatic. It is only with statutes specifically invalidated that revival has been seen as at all problematic and, as this part of the text indicates, even in this context courts have almost uniformly found that revival occurs. 
Cummings for an opinion on the status of the District of Columbia's statute. The Attorney General responded,

The decisions are practically in accord in holding that the courts have no power to repeal or abolish a statute, and that notwithstanding a decision holding it unconstitutional a statute continues to remain on the statute books; and that if a statute be declared unconstitutional and the decision so declaring it be subsequently overruled the statute will then be held valid from the date it became effective. ${ }^{43}$

Enforcement of the statute followed without congressional action. ${ }^{44}$

When this enforcement was challenged, the Municipal Court of Appeals for the District of Columbia in Jawish $v$. Morlet ${ }^{45}$ held that the decision in West Coast Hotel had had the effect of making the statute enforceable. The court observed that previous opinions addressing the revival issue

proceed on the principle that a statute declared unconstitutional is void in the sense that it is inoperative or unenforceable, but not void in the sense that it is repealed or abolished; that so long as the decision stands the statute is dormant but not dead; and that if the decision is reversed the statute is valid from its first effective date. ${ }^{46}$

The court declared this precedent sound since the cases were "in accord with the principle 'that a decision of a court of appellate jurisdiction overruling a former decision is retrospective in its operation, and the effect is not that the former decision is bad law but that it never was the law." "47 Adkins was thus, and had always been, a nullity. The court acknowledged that, after Adkins, it had been thought that the District of Columbia's minimum wage statute was unconstitutional. As the court put it, " $[\mathrm{J}]$ ust about everybody was fooled." "48 Nonetheless, the court's view was that since the minimum wage law had always been valid, although for a period judicially unenforceable, there was no need to reenact it. ${ }^{49}$

Almost all other courts that have addressed the issue of whether a statute that has been found unconstitutional can be revived have reached the same result as the Jawish court, using a similar formalistic

43. 39 Op. Att'y Gen. 22, 22-23 (1937).

44. See Jawish v. Morlet, 86 A.2d 96, 97 (D.C. 1952) (effect of overruling a case is that the former decision was never valid). Congress did amend the minimum wage act prior to Jawish. See id. An argument could be made that in amending the statute after West Coast Hotel Congress was in effect repassing the statute, thus rendering the revival issue moot. The Municipal Court of Appeals did not, however, consider such an argument.

45. 86 A.2d 96, 97 (D.C. 1952).

46. Id. (emphasis added).

47. Id. (quoting Ruppert v. Ruppert, 134 F.2d 497, 500 (D.C. Cir. 1942)).

48. Id. (quoting Warring v. Colpoys, 122 F.2d 642, 646 (D.C. Cir.), cert. denied, 314 U.S. 678 (1941)).

49. See id. 
analysis. ${ }^{50}$ The sole decision in which a court adopted the nonrevival position is Jefferson $v$. Jefferson, ${ }^{51}$ a poorly reasoned decision of the Louisiana Supreme Court. The plaintiff in Jefferson sought child support and maintenance from her husband. She prevailed at the trial level; he filed his notice of appeal one day after the end of the filing period established by the Louisiana Uniform Rules of the Court of Appeals. The Court of Appeals rejected his appeal as untimely, even though the Louisiana Supreme Court had previously found that the applicable section of the Uniform Rules violated the state constitution. One of Ms. Jefferson's arguments before the state Supreme Court was that that court's previous ruling had been erroneous and that the rules should therefore be revived. In rejecting this claim and in finding for the husband, the Court stated:

Since we have declared the uniform court rule partially unconstitutional, it appears to be somewhat dubious that we have the right to reconsider this ruling in the instant case as counsel for the respondent judges urges us to do. For a rule of court, like a statute, has the force and effect of law and, when a law is stricken as void, it no longer has existence as law; the law cannot be resurrected thereafter by a judicial decree changing the final judgment of unconstitutionality to constitutionality as this would constitute a reenactment of the law by the Court-an assumption of legislative power not delegated to it by the Constitution. ${ }^{52}$

The Louisiana Court thus took a mechanical approach to the revival question. According to its rationale, when a statute is found unconstitutional, it is judicially determined never to have existed. Revival therefore entails judicial legislation and thereby violates constitutionally mandated separation of powers: because the initial legislative passage

50. As the Indiana Supreme Court stated in Pierce v. Pierce, 46 Ind. 86, 95 (1874): "It was not the overruling of those cases which gave validity to the statutes; but the cases having been overruled, the statutes must be regarded as having been all the time the law of the State." Similarly, the Florida Supreme Court, in deciding that the overruling decision revived the unconstitutional statute, used the same metaphor as the Jawish Court: "[T]hough a statute declared unconstitutional becomes inoperative, it is not dead, only dormant." State ex rel. Badgett v. Lee, 22 So. 2d 804, 806 (Fla. 1945). For other state court decisions embracing the revival principle, see Christopher v. Mungen, 55 So. 273, 280 (Fla. 1911) (statute inoperative while invalidating decision stands but enforceable upon reversal of that decision); State v. O'Neil, 126 N.W. 454, 454 (Iowa 1910) (dicta stating that a statute previously held unconstitutional is valid and enforceable without reenactment when the supposed constitutional amendment has been removed); McCollum v. McConaughy, 119 N.W. 539, 541 (Iowa 1909); State v. Douglas, 278 So. 2d 485, 491 \& n.6 (La. 1973) (dicta overruling an invalidating decision and applying challenged statute); State ex. rel. Moore v. Molpus, 578 So. 2d 624, 638 (Miss. 1991) (dicta refusing to overrule an invalidating decision in part out of concern for the effects of the statute if revived).

51. 153 So. 2d 368 (La. 1963), aff'd, 163 So. 2d 74 (La. 1964).

52. Id. at 370 (citations omitted). 
of the bill has no legitimacy, the bill's force is considered to be purely a creature of judicial decision-making.

Jefferson has little analytic appeal. Its view of the separation of powers doctrine is too simplistic. Contrary to the Jefferson rationale, a "revived" law is not the pure product of judicial decision-making. It is, instead, a law that once gained the support of a legislature and that has never been legislatively repealed. Its legitimacy rests on its initial legislative authorization. Moreover, the view that a statute that has been found unconstitutional should be treated as if it never existed may have had some support in the early case law, but it has been clearly rejected by the Supreme Court. Instead of treating all statutes that it has found unconstitutional as if they had never existed, the Court has recognized a range of circumstances in which people who rely on an overturned decision are protected. Indeed, as will be developed, the doctrine of prospective overruling evolved to shield from harm those who relied on subsequently overruled judicial decisions. ${ }^{53}$ In short, the one case in which there was a holding that a statute did not revive does not offer a convincing rationale for nonrevival.

\section{Commentators}

Commentators have generally agreed with the overwhelming majority of courts that an overruling decision has the effect of automatically reviving statutes. For example, Erica Frohman Plave observed that revival was a necessary function of the limited scope of a judicial determination of unconstitutionality: "Such laws [laws found unconstitutional] are merely unenforceable until such time as they are found valid." 54 Professor Gerald Gunther has pronounced Attorney General Cummings's conclusion that Adkins 'simply 'suspend[ed]' enforcement" 55 of the District of Columbia minimum wage statute "persuasive[]," 56 and Professor Melville Nimmer similarly declared that "[i]t seems clear that Attorney General Homer Cummings' opinion was correct." 57 Finally, Professor Oliver Field noted that a statute that has been found unconstitutional becomes enforceable when the case in which it was held unconstitutional is reversed because "[a] declaration of unconstitutionality does not operate as a repeal of a statute." 58

53. See infra notes $90-108$ and accompanying text; see also text accompanying notes 87-89 (discussing qualified immunity for government officials who rely on existing law). One final point about Jefferson merits mention: The Louisiana Supreme Court has subsequently embraced the revival position, though it did so without overruling (or even acknowledging) Jefferson. See State v. Douglas, 278 So. 2d 485, 491 \& n.6 (1973).

54. Erica Frohman Plave, Note, The Phenomenon of Antique Laws: Can a State Revive Old Abortion Laws in a New Era?, 58 Geo. Wash. L. Rev. 111, 124 (1989).

55. Gerald Gunther, Constitutional Law 28 (12th ed. 1991) (quoting 39 Op. Att'y Gen. 22, 22 (1937)).

56. See id.

57. Nimmer, supra note 41 , at 1412 .

58. Oliver P. Field, The Effect of an Unconstitutional Statute 10 (Di Capo Press 
All of these analyses rest on a problematic premise. Implicit in the scholarly articles-and in the state judicial decisions and in the Supreme Court case law previously discussed-is the idea that revival

1971) (1935). For other conclusions similar to those mentioned in the text, $\rightarrow$ Earl T. Crawford, The Legislative Status of an Unconstitutional Statute, 49 Mich. L. Rev. 645, 651 (1951) ("The overruling decision removes the bar and the statute becomes promptly effective without legislative re-enactment ....."); Paul B. Linton, Enforcement of State Abortion Statutes after Roe: A State-by-State Analysis, 67 U. Det. L. Rev. 157, 237 (1990) (following Professor Field); Mark Graham, Note, State v. Douglas: Judicial 'Revival' of an Unconstitutional Statute, 34 La. L. Rev. 851 (1974) (arguing that statute is revived when holding of unconstitutionality is reversed because initial holding merely prevented enforcement of statute).

This Article focuses on the general question of whether a statute that is inconsistent with a governing judicial decision becomes enforceable when that decision is reversed. The issue of the potential revival of abortion statutes is used in this Article primarily to illustrate the larger theoretical issues raised by this question. It should be added, however, that there are other particularly strong arguments against revival of abortion statutes. Indeed, the anti-revival position would be compelling if Roe were to be overturned and an attempt were then made to enforce the pre-Roe criminal abortion statutes remaining on the books. With respect to older abortion statutes (such as the 1855 criminal abortion statute at issue in Weeks), there is a strong argument that the statutes violate the Equal Protection Clause because the "statutory objective . . . reflects archaic and stereotypic notions." Mississippi Univ. for Women v. Hogan, 458 U.S. 718 , 725 (1982). In addition, there is Supreme Court precedent indicating that, when legislation is of marginal constitutionality, the statute will be enforced only if the legislature considered the legislation's impact on constitutional interests. See Califano v. Goldfarb, 430 U.S. 199, 223 n.9 (1977) (Stevens, J., concurring) ("Perhaps an actual, considered legislative choice would be sufficient to allow this statute to be upheld, but that is a question I would reserve until such a choice has been made."); Greene v. McElroy, 360 U.S. 474, 507 (1959) (requiring showing that legislative body gave "careful and purposeful consideration" to "decisions of great constitutional dimension and import"); Kent v. Dulles, 357 U.S. 116, 129 (1958) ("[I]f . . 'liberty' is to be regulated, it must be pursuant to the law-making functions of the Congress."). Abortion statutes passed by legislatures that had not considered the statutes' impact on women's constitutional rights would then be unenforceable; with respect to pre-Roe statutes, it is almost definitional that legislatures failed to consider relevant constitutional concerns. Finally, there is a separation of powers issue when a long unenforced criminal statute becomes enforced through the unilateral actions of executive branch prosecutors, rather than because of a considered legislative judgment. For further development of these arguments, see Brief of Amici Curiae NARAL at 21-41, Weeks v. Connick, 733 F. Supp. 1036 (E.D. La. 1990) (No. 73-469) [hereinafter NARAL Brie $\rightarrow$ Reva B. Siegel, Reasoning from the Body: A Historical Perspective on Abortion Regulation and Questions of Equal Protection, 44 Stan. L. Rev. 261, 356-57 \& n.386 (1992); Teresa L. Scott, Note, Burying the Dead: The Case Against Revival of Pre-Roe and Pre-Casey Abortion Statutes in a Post-Casey World, 19 N.Y.U. Rev. L. \& Soc. Change 355, 370-81 (1993). It should also be added that, if Roe were to be overturned, the argument that due process bars prosecution of those women who had abortions before issuance of the overruling decision would be compelling. See Cox v. Louisiana, 379 U.S. 536, 570-71 (1965) (holding that due process clause does not permit conviction of individuals who demonstrated at site at which officials had told them they could demonstrat $\rightarrow$ Richard H. Fallon, Jr. and Daniel J. Meltzer, New Law, Non-Retroactivity, and Constitutional Remedies, 104 Harv. L. Rev. 1731, 1745 n.65 (1991) ("The retroactive application of a new decision that effectively criminalized prior conduct that had been previously held immune from prosecution would presumably deny due process."). 
reflects appropriate judicial deference to majoritarian decision-making. The majority speaks when it passes the statute. For a time, the courts may have blocked the majority's will. But, having determined that the majority was in fact empowered to pass the statute originally, the court should simply remove the bar on enforcement and, by allowing enforcement, permit the majority's will again to govern.

What this analysis misses is that the initial judicial opinion can have a transformative effect on majoritarian decision-making. The fact that "just about everybody was fooled" 59 is consequential. People generally assume that a judicial decision is final or unlikely to be reversed and act accordingly. That a statute remains on the books after it has been found unconstitutional may say very little about what the majority of the population currently thinks about that statute. Such a statute may not be repealed even though it no longer has majoritarian support. Part II develops this insight and its significance.

Moreover, there may be circumstances in which-given a statute that is sufficiently constitutionally problematic to have been at one time inconsistent with governing judicial interpretations of constitutional law-it is appropriate to force the legislature to reconsider its position on the statute itself. This is the topic of Part III of this Article.

\section{Political Reliance}

The law promotes reliance on judicial decisions through various doctrines. When courts adopt new rules of law, they are able to protect those individuals who have acted in reliance on the old rule of law through prospective overruling. In tort suits, limited immunity shields government officials who relied on an old rule of law. A primary end of stare decisis is to safeguard those who have relied on judicial decisions.

An invalidating judicial decision affects the political decisions that people make. Opponents of a statute that has been either held to be unconstitutional or that is unconstitutional under a rule of law that a court has announced in invalidating another statute take the invalidating decision into account as they decide whether to spend their political capital on repeal. Political actors have a finite set of resources that they can deploy to influence legislative (and other) processes; the invalidating decision affects the way those resources-their political capital-are spent. In reliance on the invalidating decision, political actors are likely not to seek repeal or not to seek it vigorously. Similarly, they are likely not to focus their efforts on opposing a proposed new statute that would be unenforceable under the invalidating decision. Such political reliance on the invalidating decision is at least as deserving of protection as other reliance interests that are currently protected by the law.

To protect such political reliance, in certain circumstances courts

59. Jawish v. Morlet, 86 A.2d 96, 97 (D.C. 1952) (quoting Warring v. Colpoys, 122 F.2d 642, 646 (D.C.), cert. denied, 314 U.S. 678 (1941)). 
should be able to use the technique of prospective overruling in evaluating the enforceability of statutes. In other words, when there has been political reliance on an invalidating decision that is subsequently overturned, a court should have the power to evaluate a statute's enforceability using the rule of law enunciated in the invalidating decision, rather than the rule of law set forth in the overruling decision. The overruling decision would then operate only prospectively-permitting enforcement of a statute passed after, but not one passed before, its announcement.

The judicial power to apply the overruling decision only prospectively can be justified on choice of law grounds. The new rule of law is, under this approach, almost like a constitutional amendment, and constitutional amendments have been held not to validate statutes passed prior to the amendment's ratification (unless they were intended to do so). A better approach, however, is to regard prospective overruling as an exercise of the judicial power to fashion appropriate constitutional remedies. Under this approach, the question of whether to apply the technique of prospective overruling will turn on the equities of the situation. We conclude this part with a discussion of when prospective overruling is appropriate. Specifically, we will argue that, with respect to potential revival of a particular statute, a court should take account of: (1) the amount of time between the invalidating decision and the overruling decision; (2) how clear it was that the statute at issue was unconstitutional under the invalidating decision; (3) the relative timing of the statute's passage and the relevant judicial decisions.

\section{A. The Effect of a Finding of Unconstitutionality on the Political Process}

When a court finds a statute unconstitutional and bars its enforcement, it alters the stakes involved in that statute's repeal. The decision also alters the stakes involved in passage of a new statute, if that statute is clearly unconstitutional under the rule of law enunciated in the decision. Because the stakes are altered, the operations of the political processes are altered. Political actors know that, at least in the short term, a statute that has been found unconstitutional or that is clearly unconstitutional under governing case law will not be enforced. Given our legal system's respect for precedent, they also know that the statute is presumptively unenforceable in the long term. Indeed, political actors may act as if overruling were not a possibility, as if the statute would never be enforceable.

It is hard to mobilize either the legislative or popular support needed to secure the repeal of a statute when it is unenforced and when it has been pronounced unconstitutional. If doctors who performed abortions were being sentenced to ten years of hard labor, as the Louisiana statute at issue in Weeks permitted, there would have been ongoing testing as to whether that result was one desired by the people of Louisiana. But because of Roe there was no enforcement of the stat- 
ute and hence no rallying point for repeal. As the Maryland Supreme Court suggested in Johnson $v$. State ${ }^{60}$ inertia can keep statutes pronounced unconstitutional on the books, regardless of whether or not they have current majoritarian support:

[A]n unconstitutional act is not a law for any purpose, cannot confer any right, cannot be relied upon as a manifestation of legislative intent, and, "is, in legal contemplation, as inoperative as though it had never been passed." Norton v. Shelby County, 118 U.S. 425, 442, 6 S.Ct. 1121, 30 L.Ed. 178 (1886); Chicago, Ind. \& L. Ry. Co. v. Hackett, 228 U.S. 559, 566-67, 33 S.Ct. 581, 57 L.Ed. 966 (1913). Because of this principle, legislative bodies often fail to repeal unconstitutional statutes, deeming them obsolete matter which can be later deleted in the course of a general revision or recodification of the laws on the particular subject. ${ }^{61}$

The story of New York Assemblyman George Michaels and his vote on the 1970 measure to repeal New York's criminal abortion statute illustrates how differently the political process can function when decisions have immediate consequences. Michaels represented a district that was sixty-five percent Catholic, and he decided that in order to save his seat he had to vote against repeal. Nonetheless, his family had urged him to vote to eliminate the existing statute. His son, an intern in a Cincinnati ghetto, had told him of the suffering that he had seen caused by illegal abortions. When Michaels told his wife that his planned vote was inconsequential since repeal would inevitably occur in a few years, she replied, "In the meantime, thousands of women will be butchered in underworld abortion[s]." 62

Despite these arguments, Michaels initially voted to keep the criminal abortion statute on the books, and then, as the vote concluded but before it was finalized, realized that repeal would lose by one vote. Just before the final tally was announced, Michaels took the floor. The New York Times reported:

Assemblyman George M. Michaels of Auburn, his hands trembling and tears welling in his eyes, stopped the roll-call only seconds before the clerk was to announce that the reform bill had been defeated for lack of a single vote. ... "I realize, Mr. Speaker," Mr. Michaels said, "that I am terminating my political career, but I cannot in good conscience sit here and allow my vote to be the one that defeats this bill-I ask that my vote be changed from "no" to "yes." 63

For Assemblyman Michaels, recognition of the consequential nature of

60. 315 A.2d 524 (Md. 1974).

61 . Id. at 528 .

62. Laurence H. Tribe, Abortion: The Clash of Absolutes 48 (1990) (quoting from Lawrence Lader, Abortion II: Making the Revolution 145 (1973)).

63. Id. (quoting from Bill Kovach, Abortion Reform Is Voted by the Assembly, N.Y. Times, Apr. 10, 1970, at 1). 
his vote powerfully influenced what he did. Clearly, if Roe had been the law of the land in 1970, Michaels would have voted against repeal.

A judicial decision invalidating a statute also skews the political dynamic because, as a result of that decision, proponents and opponents of the statute will attach different levels of symbolic importance to its repeal. Similarly, they will attach different levels of symbolic importance to the passage of new statutes that are also unconstitutional under the invalidating decision. Again, the skewing favors the proponents of the invalidated statute. The proponents, having lost in the courts, place a premium on legislative endorsement of their position: the legislature alone can provide a statement in favor of their views by an official governmental actor. Opponents of a statute will attach less symbolic value to what the legislature does. For them, the effect of legislative endorsement will only be cumulative, since the courts have already embraced their position.

This difference in symbolic importance for the two sides can alter the political process so that it produces a result inconsistent with majority wishes. A legislator will incur the enmity of those who support an "unconstitutional" bill by working for its repeal or opposing similar legislation; she is unlikely to win offsetting support from the bill's opponents. The fate of an Arkansas statute that required public schools to allocate as much time to the teaching of creation science as to evolution illustrates this phenomenon. Although understood to be unconstitutional, the statute was passed by the legislature almost without discussion. ${ }^{64}$ The President Pro Tempore of the Senate explained, "[I]t was meaningless, just a piece of junk, so why not vote for it." 65 Had opponents of the bill attached as much importance to blocking it as proponents did to ensuring its passage, the Senator would not have made that statement. But because the statute's symbolic importance was different for the two camps, he voted in favor of the bill.

Thus far the discussion has concerned the ways in which the invalidating decision creates incentives that work both against the repeal of existing statutes that are unenforceable under the invalidating decision and in favor of the passage of similarly unenforceable statutes. It is also important to recognize that there are ways in which the invalidating decision simply alters the political calculus in ways that make it impossible to determine whether a particular statute would be on the books if the invalidating decision had never been issued. One can imagine a range of responses on both sides to an invalidating decision. Because of the decision, opponents of the statute might devote little energy to its repeal and focus instead on, say, the repeal of enforceable statutes that they oppose. Supporters of the "unconstitutional" statute might

64. $: \rightarrow$ Allan C. Hutchinson \& Derek Morgan, Calabresian Sunset: Statutes in the Shade, 82 Colum. L. Rev. 1752, 1763 n.36 (1982) (reviewing Guido Calabresi, A Common Law for the Age of Statutes (1982)).

$t \rightarrow$ Id. at 1764 (quoting President Pro Tempore of the Senate, Ben Allen). 
focus their energy on passing legislation of marginal constitutionality in order to test the exact contours of the invalidating decision. Alternately, opponents of a statute might think reversal of the invalidating decision sufficiently likely that they will devote more resources to repeal than will proponents of the statute, who may assess the likelihood of reversal differently or who may choose to pursue other ends for strategic reasons. What is clear, however, is that, after the invalidating judicial decision is issued, political actors take it into account and the decision thereby affects the political process.

Two leading constitutional law cases further illustrate the operation of political reliance. The Civil Rights Act of $1875^{66}$ was the last triumph of the brief heyday of Radical Reconstruction. Indeed, the bill was passed after the electoral tide had shifted: A Republicandominated Congress enacted it in March 1875, days before the Democrats who had won control of the House in the 1874 election took their seats. ${ }^{67}$ That statute provides for criminal penalties for racial discrimination in public accommodations and for civil penalties for such discrimination without the need of securing injunctive relief. The Supreme Court held the Act unconstitutional in 1883 in the Civil Rights Cases, ${ }^{68}$ stating that neither the Thirteenth nor the Fourteenth Amendment provided Congress with the power to enact the legislation. ${ }^{69}$ Since that time the statute has been unenforced. ${ }^{70}$ Current case law makes it clear that Congress has the power to ban such discrimination under the Commerce Clause. ${ }^{71}$ If a statute that has been found uncon-

66. Act of March 1, 1875, ch. 114, 18 Stat., 335 (1875). Sections 3 and 4 of the act have been repealed. See Act of June 25, 1948, ch. 645, § 21, 62 Stat. 862, (codified as amended at 8 U.S.C. $\S \S 44-45)$ (1988). Sections 1 and 2 of the Act have never been repealed, while Section 5 is codified at 42 U.S.C. $\S 1984$ (1988). See Historical Note to 42 U.S.C.A. $\$ 1984$ (West 1981) (noting that the Civil Rights Act of 1875 has been codified at this section but is not printed because it is "obsolete," the Supreme Court having held it unconstitutional). For a discussion of the Act and its history, see Nimmer, supra note 41 , at $1394-98$.

67. See Eric Foner, Reconstruction: America's Unfinished Revolution, 1863-1877, at 553-56 (1988).

68. 109 U.S. 3 (1883).

69. See id. at 25 ("On the whole we are of opinion, that no countenance of authority for the passage of the law in question can be found in either the Thirteenth or Fourteenth Amendment of the Constitution; and no other ground of authority for its passage being suggested, it must necessarily be declared void ....").

70. See Historical Note to 42 U.S.C.A. $§ 1984$ (West 1981); Nimmer, supra note 41 , at $1394-98$.

71. The leading case on point is Heart of Atlanta Motel, Inc. v. United States, 379 U.S. 241 (1964). Heart of Atlanta did not overrule the Civil Rights Cases. Rather, it distinguished them on the grounds that the defenders of the statute in the earlier case had not based their claim of federal power on the Commerce Clause, relying instead on the Thirteenth and Fourteenth Amendments. See id. at 252. At the same time, it indicated that those providing public accommodations in 1881 might not have been engaged in interstate commerce, but that by 1964 (the time of the Heart of Atlanta decision), they were so engaged. See id. at 251. 
stitutional can be revived by subsequent case law, the statute would presumably be enforceable today. But given the enduring powers of segregationist forces in national politics in the years after 1883 and through much of the twentieth century, it is almost inconceivable that the statute would not have been repealed if it had been perceived as a possibility that it might become enforceable, and yet it has never been repealed.

More recently, the response to Roe demonstrates the consequences of political reliance. In the years from 1967 to 1973, the period immediately before Roe was handed down, nineteen states reformed their abortion laws. ${ }^{72}$ By apparently ending the need for this process, Roe also largely ended the process itself, as the seventeen unenforced but unrepealed pre-Roe criminal abortion statutes suggest. ${ }^{73}$ When Roe was announced, one Planned Parenthood official recalled a decade later, "Most of us really believed that was the end of the controversy. The Supreme Court had spoken, and while some disagreement would remain, the issue had been tried, tested and laid to rest." 74 Instead of fighting over repeal of unenforceable pre-Roe statutes, pro-choice and pro-life forces in the wake of Roe primarily struggled over whether there should be a constitutional amendment on abortion and over legal issues that Roe had left open; this was particularly true in the years before 1980, when President Reagan's election suggested that, through new appointments to the Supreme Court, Roe might be overturned. Thus, at the federal level, the post-Roe congressional debate in the years before 1980 largely focused on federal funding for abortions. At the state level, debate centered on whether legislation should be enacted that burdened a woman's attempt to exercise the right Roe recognized. ${ }^{75}$

Roe skewed the political process in two additional ways. First, as Professor Tribe has observed:

[The pro-life movement] harnessed the power of single-issue politics to elect public officials who believed, as they did, that abortion was murder and that it should be outlawed. Ironically, Roe contributed to the success of [the pro-life] movement because it prevented government from legislatively restricting access to abortion. Those who did not agree with the right-to-life position thus could vote for pro-life candidates with whom they otherwise agreed without concern that antiabortion views would actually be enacted into enforceable laws. ${ }^{76}$

72. See Tribe, supra note 62, at 49 (citing Mary Ann Glendon, Abortion and Divorce in Western Law (1987)).

73. See 1993 NARAL, supra note 5 , at vi.

74. See Flora Davis, Moving the Mountain: The Women's Movement in America Since 1960, at 181 (1991) (quoting Planned Parenthood executive).

75. See Tribe, supra note 62 , at $139-60$.

76. Id. at 16. Professor Tribe assumes that pro-life and pro-choice voters behave 
Tribe's point here is bolstered by the fact that Webster produced the opposite result. A National Abortion Rights Action League (NARAL) survey conducted in 1989, shortly after the decision in Webster, concluded that only twenty-three of the ninety-nine state legislative bodies favored keeping abortion legal. After Webster suggested that Roe was imperiled, pro-choice support at the state legislative level grew dramatically. In 1993, NARAL determined that fifty state legislative bodies supported legalized abortion. ${ }^{77}$

Second, by making a class of abortion legislation unenforceable, Roe ironically made such legislation easier to pass. In his amicus brief in Webster, Solicitor General Charles Fried observed about this process:

[B]ecause legislators know that whatever they enact in this area will be subject to de novo review by the courts, they have little incentive to try to moderate their positions. The result, all too often, has been statutes that are significant primarily because of their highly "inflammatory" symbolic content. . . . This process has undermined the accountability of legislative bodies and has disserved the courts and the Constitution. ${ }^{78}$

Like Arkansas's creation science statute, then, these "unconstitutional" abortion statutes show that proponents of an unconstitutional statute attach greater importance to passing such statutes for symbolic reasons than their opponents attach to blocking them.

Thus, the four cases surveyed-Assemblyman Michaels and New York's abortion statute, the Arkansas Senator and creation science, the political responses to the Civil Rights Cases and Roe-illustrate the critical points about political reliance. First, those who oppose the invalidated statute-those, in other words, who are sympathetic to the invalidating decision-rely on the invalidating decision as they conduct their political activities. Second, judicial invalidation of a statute affects majoritarian political deliberation in a way that makes it incorrect to

differently: During a period in which it is clear that a woman's right to an abortion receives significant constitutional protection, pro-life voters are more likely to vote on the basis of a candidate's stand on abortion than are pro-choice voters. This assumption makes sense if pro-life voters are more likely to be one-issue voters than are pro-choice voters. We believe this assumption is correct, but Tribe's insight is not necessarily generalizable to revival issues outside of the abortion context. In other areas, it may be the case that opponents of a statute that has been held unconstitutional are more likely to judge a candidate on the basis of her stand on that statute than are proponents of the statute.

77. See 1993 NARAL, supra note 5 , at $v$.

78. Brief of the United States as Amicus Curiae at 21 n.15, Webster v. Reproductive Health Serv., 492 U.S. 490 (1989) (No. 88-605); see also NARAL Brief, supra note 58, at 24 (quoting language in the Solicitor General's brief in Webster as evidence that abortion decisions had a "distortive effect" on the political process); Guido Calabresi, The Supreme Court, 1990 Term-Foreword: Antidiscrimination and Constitutional Accountability (What the Bork-Brennan Debate Ignores), 105 Harv. L. Rev. 80, 147 n.220 (1991) (skewing effect of Roe and its progeny on political process may make revival of abortion statutes counter-majoritarian); Scott, supra note 58, at 368-70 (discussing quoted language from Solicitor General's brief in I'ebster). 
assume that either the failure to repeal an "unconstitutional" statute or the passage of an "unconstitutional" statute after a court has established a rule under which that statute is unconstitutional accurately reflects the will of the current majority. Third, not only does judicial invalidation affect the political process, it tends to do so in a particular way, tilting the process towards the retention and passage of "unconstitutional" statutes.

\section{B. Protection of Reliance Interests}

As has been pointed out, courts have not recognized political reliance as an interest that merits protection when they determine to overrule a decision. In other areas of constitutional law, however, courts recognize that individuals who order their affairs in reliance on judicial decisions have a claim to protection, and doctrines have been developed that protect such reliance.

Stare decisis is such a doctrine. While the scope and rationale of stare decisis are the subject of great debate among commentators and in the courts, ${ }^{79}$ as Professor Earl Maltz has observed, "The most commonly heard justification for the doctrine of stare decisis rests on the need for certainty in the law. In planning their affairs, it is argued, people should be able to predict the legal consequences of their actions." 80 In Justice Harlan's words, stare decisis advances the "predictability required for the ordering of human affairs over the course of time." 81 Even for Chief Justice Rehnquist, who has a constrained notion of the value of stare decisis, ${ }^{82}$ reliance on judicial decisions merits protection and is a principal ground for the doctrine of stare decisis. Thus, in Payne v. Tennessee, the Chief Justice observed:

Stare decisis is the preferred course because it promotes the evenhanded, predictable, and consistent development of legal

79. For an analysis of Supreme Court Justices' competing conceptions of stare decisis, see Gerhardt, supra note 21, at 114-31. For recent scholarly analyses of the doctrine's role, see, e.g., id. at 131-45 (examining the implications of the Justice's individual approaches to preceden $\rightarrow$ Henry P. Monaghan, Stare Decisis and Constitutional Adjudication, 88 Colum. L. Rev. 723, 724 (1988) (concluding that "original understanding must give way in the face of transformative or longstanding preceden $\rightarrow \rightarrow$ Frederick Schauer, Precedent, 39 Stan. L. Rev. 571, 595 (1987) (examining the role of precedent outisde sphere of legal doctrine and within law); Geoffrey $\mathbf{R}$. Stone, Precedent, the Amendment Process, and Evolution in Constitutional Doctrine, 11 Harv. J.L. \& Pub. Pol'y 67, 67 (1988) (discussing the circumstances under which the Supreme Court may appropriately overrule a major constitutional decision).

80. Earl M. Maltz, The Nature of Precedent, 66 N.C. L. Rev. 367, 368 (1988); see also Schauer, supra note 79, at 597 ("The most commonly offered of the substantive reasons for choosing strong over weak precedential constraint is the principle of predictability"); Stone, supra note 79, at 70 ("doctrine of precedent . . . [advances] predictability in our affairs").

81. Williams v. Florida, 399 U.S. 78, 127 (1970) (Harlan, J., concurring).

82. See Gerhardt, supra note 21 , at 128-31 (viewing Rehnquist as maintaining that "precedents carry little weight in and of themselves in decision-making"). 
principles, fosters reliance on judicial decisions, and contributes to the actual and perceived integrity of the judicial process. ${ }^{83}$

The Chief Justice thus believes that the presence of reliance makes the case for stare decisis most compelling: "Considerations in favor of stare decisis are at their acme in cases involving property and contract rights, where reliance interests are involved; the opposite is true in cases . . . involving procedural and evidentiary rules." 84 In publicly explaining his decision in Payne, Chief Justice Rehnquist has indicated that the basis for this distinction is his belief that "few criminals would base their decision to commit a crime" on Supreme Court evidentiary precedent, but that people making decisions on property and contracts issues do take such precedent into account. ${ }^{85}$

Even assuming that Chief Justice Rehnquist is correct as an empirical matter about whether criminals rely on precedent, there is no logical reason why the only reliance worthy of protection should be that involving decisions regarding contracts or property. Individuals rely on judicial decisions as they make noneconomic decisions, just as they do when they make economic decisions, and the former class of choices are at least as deserving of protection as the latter. The plurality opinion in Casey recognized this point, advancing it as a principal ground for its decision to embrace the doctrine of stare decisis and not to overturn Roe :

[F]or two decades of economic and social developments, people have organized intimate relationships and made choices that define their views of themselves and their places in society, in reliance on the availability of abortion in the event that contraception should fail. The ability of women to participate equally in the economic and social life of the Nation has been facilitated by their ability to control their reproductive lives. The Constitution serves human values, and while the effect of reliance on Roe cannot be exactly measured, neither can the certain cost of overruling Roe for people who have ordered their thinking and living around that case be dismissed. ${ }^{86}$

83. Payne v. Tennessee, 111 S. Ct. 2597, 2609 (1991) (majority opinion).

84. Id. at 2610.

85. Tony Mauro, Courtside: Marshall: Scant Mementos, Scattered Clerks, Legal Times, July 15, 1991, at 8, 9, quoted in Gerhardt, supra note 21, at 129.

86. Planned Parenthood v. Casey, 112 S. Ct. 2791, 2809 (1992) (plurality opinion). But see Earl M. Maltz, Abortion, Precedent and the Constitution: A Comment on Planned Parenthood of Southeastern Pennsylvania v. Casey, 68 Notre Dame L. Rev. 11, 18-32 (1992) (criticizing Casey plurality's approach to stare decisis).

Given Justice Rehnquist's narrow view of protected reliance interests, see supra notes 82-85 and accompanying text, it is not surprising that in his dissent in Casey he criticized the plurality's protection of this reliance interest. He wrote:

As the joint opinion apparently agrees, any traditional notion of reliance is not applicable here.... The joint opinion thus turns to what can only be described as an unconventional-and unconvincing-notion of reliance, a view based on the surmise that the availability of abortion since Roe has led to "two decades of 
Courts have also protected reliance interests in deciding cases concerning constitutional torts. Government officials are protected from liability when their actions are consistent with then-existing judicial interpretations, even if those interpretations subsequently change. Thus, in Harlow v. Fitzgerald, ${ }^{87}$ the Court held "government officials performing discretionary functions [] generally are shielded from liability for civil damages insofar as their conduct does not violate clearly established statutory or constitutional rights of which a reasonable person would have known." 88 According to the Harlow majority, the costs of not shielding government officials from tort liability include "distraction ... from their governmental duties, inhibition of discretionary action, and deterrence of able people from public service." 89

Finally, reliance interests have been protected when courts have prospectively overruled preceding judicial decisions (or, to put it another way, when they have applied the doctrine of non-retroactivity). When courts prospectively overrule an earlier decision, they refrain from applying the new law to events that predate its announcement. As Chief Justice Burger wrote in his plurality opinion in Lemon $v$. Kurtzman,${ }^{90}$ nonretroactivity reflects the notion that "statutory or even judge-made rules of law are hard facts on which people must rely in making their decisions and in shaping their conduct." 91

The original jurisprudential basis for the opposing doctrine that a decision on constitutionality must be applied retroactively is evidenced by the Supreme Court's decision in Norton $v$. Shelby County. ${ }^{92}$ (This is the case that the Maryland Supreme Court invoked, in the language we have previously quoted from Johnson $v$. State, to explain why legislators do not always repeal statutes that are found unconstitutional.) ${ }^{93}$ Norton involved a suit by bondholders who sought to enforce payments of bonds issued by the Shelby County Board of Commissioners. The Commissioners had been appointed pursuant to a state statute that the

economic and social developments" that would be undercut if the error of Roe were recognized.

Casey, 112 S. Ct. at 2861-62 (citations omitted) (Rehnquist, C.J., dissenting).

87. 457 U.S. 800 (1982).

88. Id. at 818; see also Mitchell v. Forsyth, 472 U.S. 511, 534-35 (1985) (although his actions violated Fourth Amendment, former Attorney General entitled to qualified immunity; Court observes that, at time of Attorney General's actions, two district court opinions suggested they were legal); Davis v. Scherer, 468 U.S. 183, 193-95 (1984) (noting that defendant's conduct was constitutional under law of circuit as reason for granting qualified immunity). See generally Fallo \& Meltzer, supra note 58, at 1749-53 (discussing qualified immunity in constitutional tort actions).

89. 457 U.S. at 816. But $\rightarrow$ Akhil R. Amar, Of Sovereignty and Federalism, 96 Yale L.J. 1425, 1485-88 (1987) (criticizing granting immunity for government officials as removing necessary check)

90. 411 U.S. 192 (1973).

91. Id. at 199 (plurality opinion).

92. 118 U.S. 425 (1886).

93. See supra text accompanying notes $60-61$ 
Tennessee Supreme Court found-after the bonds were issued-to be violative of the state constitution. In rejecting the bondholders' claims, United States Supreme Court Justice Field asserted: “An unconstitutional act is not a law; it confers no rights; it imposes no duties; it affords no protection; it creates no office; it is, in legal contemplation, as inoperative as though it had never been passed."94 The bondholders thus had no cognizable claim because, from a legal point of view, the bond-issuing authority had never existed. Norton came to stand for a proposition that was as applicable to overruling decisions as to the effect of judicial holdings of statutory unconstitutionality: any reliance on the law as it appeared prior to the ultimate judicial ruling would not be protected. ${ }^{95}$

There were a few nineteenth century cases in which courts, rejecting the implications of Norton, applied their decisions prospectively, ${ }^{96}$ but frequent use of the doctrine of prospective overruling began only after it was championed by Benjamin Cardozo. ${ }^{97}$ In his 1921 book, The Nature of the Judicial Process, Cardozo wrote:

[I]n the vast majority of cases the retrospective effect of judgemade law is felt either to involve no hardship or only such hardship as is inevitable where no rule has been declared. I think it is significant that when the hardship is felt to be too great or to be unnecessary, retrospective operation is withheld. Take the cases where a court of final appeal has declared a statute void, and afterwards, reversing itself, declares the statute valid. Intervening transactions have been governed by the first decision. What shall be said of the validity of such transactions when the decision is overruled? Most courts in a spirit of realism have held that the operation of the statute has been suspended in the interval. It may be hard to square such a ruling with abstract dogmas and definitions. When so much else that a court does, is done with retroactive force, why draw the line here? The answer is, I think, that the line is drawn here, because the injustice and oppression of a refusal to draw it would be so great as to be intolerable. ${ }^{98}$

Having argued as a scholar for prospective overruling, Cardozo as

94. 118 U.S. at 442.

95. See Oliver P. Field, supra note 58, at 1-2; Plave, supra note 54, at 115 .

96. See Schaefer, supra note 26, at 2 (citing Bingham v. Miller, 17 Ohio 445 (1848)). In addition, in Gelpcke v. City of Dubuque, 68 U.S. (1 Wall.) 175 (1863), and related municipal bond cases, the Supreme Court ruled on constitutional grounds that states could not give overruling decisions retroactive effect if that would cause the impairment of vested or contractual rights. See generally Walter V. Schaefer, The Control of "Sunbursts": Techniques of Prospective Overruling, 42 N.Y.U. L. Rev. 631, 631-41 (1967) (discussing early cases and scholarly arguments concerning prospective application of decisions).

97. See Schaefer, supra note 26 , at 3 .

98. Benjamin N. Cardozo, The Nature of the Judicial Process 146-47 (1921) (citations omitted). 
a Justice pronounced it constitutional in Great Northern Railway Co. v. Sunburst Oil E Refining Co. ${ }^{99}$ The Montana Supreme Court in a 1921 decision had held that shippers could recover the overcharge for excessive rates. Sunburst then sued Great Northern Railway to recover such an overcharge. The Montana Supreme Court overruled the decision that would have authorized Sunburst's recovery, but also elected not to apply that result retroactively. Thus, Sunburst prevailed because the Court applied the rule established in the earlier case. But the Court also found that rule inapplicable to future claimants. The railroad contended that the Montana Supreme Court decision violated due process. Writing for a unanimous Court, Justice Cardozo stated:

We think the federal constitution has no voice upon the subject [of whether a new rule must be applied retroactively]. A state in defining the limits of adherence to precedent may make a choice for itself between the principle of forward operation and that of relation backward. It may say that decisions of its highest court, though later overruled, are law none the less for intermediate transactions. Indeed there are cases intimating, too broadly that it must give them that effect; but never has doubt been expressed that it may so treat them if it pleases, whenever injustice or hardship will thereby be averted. ${ }^{100}$

The doctrine of prospective overruling assumed new prominence in 1965 with the Supreme Court's decision in Linkletter v. Walker. ${ }^{101}$ In Linkletter, the Court decided not to give full retroactive effect to its decision in Mapp v. Ohio ${ }^{102}$ that state courts had to exclude evidence obtained in violation of the Fourth Amendment. Two years later, in Stovall v. Denno, ${ }^{103}$ the Court specified the factors to be used in determining when a decision should be retroactive: "(a) the purpose to be served by the new standards, (b) the extent of the reliance by law enforcement authorities on the old standards, and (c) the effect on the administration of justice of a retroactive application of the new standards."104

The Stovall test influenced the Supreme Court's formulation in

99. 287 U.S. 358,364 (1932).

100. Id. (citation omitted).

101. 381 U.S. 618 (1965), overruled by Griffith v. Kentucky, 479 U.S. 314, 320-28 (1987).

102. 367 U.S. $643,654-55$ (1961).

103. 388 U.S. 293 (1967).

104. Id. at 297. Although it has been extended to civil cases, this test is no longer applied in the criminal context. See Griffith v. Kentucky, 479 U.S. 314, 328 (1987) (complete retroactive application of new law to cases pending on direct review). For discussion of Griffth, see infra notes 125-127 and accompanying text. As Griffith indicates, prospective overruling has provoked controversy among members of the Court and it has not been consistently applied. The Justices have disagreed as to when the technique should be used and, more fundamentally, as to whether it is legitimate. The relevant case law and criticism are discussed infra at notes 155-140 and accompanying text; that part of the Article also presents our defense of prospective 
Chevron Oil Co. v. Huson ${ }^{105}$ of the approach to be employed in the civil context to determine whether a decision should be retroactively applied:

First, the decision to be applied nonretroactively must establish a new principle of law, either by overruling clear past precedent on which litigants may have relied or by deciding an issue of first impression whose resolution was not clearly foreshadowed. Second, it has been stressed that "we must . . . weigh the merits and demerits in each case by looking to the prior history of the rule in question, its purpose and effect, and whether retrospective operation will further or retard its operation." Finally, we have weighed the inequity imposed by retroactive application, for " $[w]$ here a decision of this Court could produce substantial inequitable results if applied retroactively, there is ample basis in our cases for avoiding the 'injustice or hardship' by a holding of nonretroactivity." 106

Chevron Oil involved a civil statute, rather than the Constitution. In American Trucking Ass'ns $v$. Smith, ${ }^{107}$ however, a four-member plurality of the Court, led by Justice O'Connor, held that the Chevron Oil test governed when the overruling decision reversed an opinion interpreting the Constitution. In applying Cheuron Oil, Justice O'Connor justified prospective overruling as a means to avoid hurting those who had relied on the prior decision: "When the Court concludes that a lawchanging decision should not be applied retroactively, its decision is usually based on its perception that such application would have a harsh and disruptive effect on those who relied on prior law." 108

overruling (and, specifically, of prospective overruling in the statutory context) as an exercise of the judicial remedial function.

It should be noted that in the area of habeas corpus, the Court has ruled that a petition that either rests on or seeks enunciation of a new rule of law will normally be dismissed. See Teague v. Lane, 489 U.S. 288, 316 (1989); see also Fallon \& Metzer, supra note 58, at 1746-49 (discussing Teague and subsequent case law). But see Marc M. Arkin, The Prisoner's Dilemma: Life in the Lower Courts after Teague v. Lane, 69 N.C. L. Rev. 371, 395-99 (1991) (providing a narrow reading of Teague). Habeas, however, raises unique issues. Thus, Justice Harlan, despite his criticism of prospective overruling in cases involving direct review, believed that the fact that habeas was an extraordinary remedy and the importance of finality in criminal convictions meant that new rules should generally not be applied in the habeas context. See Fallon \& Meltzer, supra note 58, at 1743-44 (discussing Justice Harlan's view of habeas and new rules).

105. 404 U.S. 97 (1971).

106. Id. at 106-07 (citations omitted). For Justice White's broad endorsement of the Chevron test, see James B. Beam Distilling Co. v. Georgia, 111 S. Ct. 2439, 2449 (1991) (White, J., concurring); for Justice O'Connor's, see id. at 2451 (O'Connor, J., dissenting); see also American Trucking Ass'ns v. Smith, 496 U.S. 167, 191 (1990) (plurality opinion).

107. 496 U.S. 167 (1990).

108. Id. at 191. 


\section{Prospective Overruling and Political Reliance}

There is thus ample precedent in the law for the notion that judicial decisions should protect at least some reliance interests. Is political reliance an interest that should be protected, and if so, how should protection be achieved?

We recognize that not all reliance interests merit protection. Notwithstanding Justice Rehnquist's comments to the contrary, a criminal might well argue against a change in the evidentiary rules on the grounds that she had, in fact, taken the current rules into account in deciding to commit a crime. ${ }^{109}$ It seems unlikely, however, that we would want to shield her from the consequences of the rule change; the purpose of rules that limit the kind of evidence that the state can introduce is not to empower the criminal, but to restrain the constable. In contrast, there are compelling reasons for encouraging political reliance.

To promote efficient political activity and to encourage deference to judicial decision-making, the judiciary should wish to encourage majoritarian bodies to interpret the Constitution in the same way as it does. Revival encourages what is in effect a form of legislative nonacquiescence. It gives critics of a judicial decision a strong incentive to oppose repeal of the invalidated statute and to work for the passage of legislation inconsistent with that decision. In the vast majority of cases, the battles over "unconstitutional" legislation will entail a squandering of political resources. Because our legal system attaches a heavy weight to precedent, relatively few invalidating decisions will be overturned. Thus, a significant amount of legislative energy will be devoted to matters of no practical importance. At the same time, revival encourages political actors to behave as if judicial decisions are transitory in nature and thus undermines faith in their finality.

Revival of previously invalidated statutes penalizes those who make good faith judgments in reliance on the rule of law enunciated in the invalidating decision. As previously pointed out, statutes that are at odds with the invalidating decision may remain on the books or be passed when, in the absence of the invalidating decision, they would have been repealed or defeated. While the law protects reliance interests out of a deep concern for fairness, in the belief that those who structure lawful activity around judicial pronouncements should not be hurt by subsequent judicial decisions to alter the rule of law, nonprotection of political reliance leads to outcomes that are both consequential and unfair.

A variant on Weeks ${ }^{110}$ illustrates the unfairness that can ensue when

109. See supra note 85 and accompanying text.

110. Weeks v. Connick, 733 F. Supp. 1036 (E.D. La. 1990). 
statutes are revived. Let us assume that Casey ${ }^{111}$ had reversed Roe ${ }^{112}$ and that Weeks had been brought after Roe had been reversed. Revival in this context would have rendered the 134-year-old statute-which may well have been on the books only because it was unenforced-automatically enforceable. Pursuant to the terms of the statute, any district attorney anywhere in the state could have prosecuted any doctor performing abortions in the state for a felony carrying a ten-year jail sentence. The threat of such prosecution could have closed all the abortion clinics in the state, forcing the physician, nurse, and counsellor employed there to seek other employment. At some point after enforcement began the statute might have been repealed or modified. But the disruption caused by enforcement would have had long-term consequences; eventual repeal could not restore the status quo ante. ${ }^{113}$

There are, then, important reasons to protect political reliance. But how can such protection be achieved? The answer to this question lies in extending the doctrine of prospective overruling, which is currently limited to events that predate judicial announcement of the new rule of law, making it applicable to statutes whose passage predates the judicial announcement of the new rule of law. In other words, courts should be able to use this doctrine in evaluating statutes passed before the overruling decision. Such prospective overruling would deal precisely with the harms associated with the failure to protect political reliance. It would allow courts to prevent the enforcement of statutes that may not reflect current majoritarian will. It would prevent the squandering of political resources. And it would bolster rather than undermine judicial authority, ensuring the fair treatment of those who base their behavior on judicial interpretations of the law. ${ }^{114}$

111. Planned Parenthood v. Casey, 112 S. Ct. 2791 (1992).

112. Roe v. Wade, 410 U.S. 113 (1973).

113. Another way in which the statute would have had a chilling effect stems from the fact that by definition, the Louisiana legislators who had passed the statute were unfamiliar with subsequent developments. Thus, the 1855 law did not speak to matters such as whether contraceptives like IUDs that prevented implantation are abortifacients and hence subject to severe criminal penalties. Until the reach of the law was clarified (or until the law itself was repealed), then, use of IUDs might have been substantially discouraged.

As previously noted, see supra note 13, after Weeks the Louisiana legislature amended and partially re-enacted its criminal abortion statute. The provision concerning abortifacients, La. Rev. Stat. Ann. § 14:88 (West 1986), was not re-enacted. Under the post-Weeks statute, doctors who perform abortions in cases other than rape or incest or to save the life of the mother are subject to criminal prosecution. See La. Rev. Stat. Ann. \& 14:87 (West Supp. 1993). This is a narrower statute than the original, which did not contain these exceptions. See La. Rev. Stat. Ann. § 14:87 (West 1986).

114. In this regard, it is possible to imagine the following counterargument against prospective overruling: Prospective overruling will destroy the incentives and the opportunity for legislatures to engage in a dialogue with courts about whether the invalidating decision should be overturned. Adherents of this argument would ask: why would a legislature pass a statute that is unenforceable under the invalidating decision? If the legislature has no incentive to do so, won't that undercut the court's ability to have 
Prospective overruling is best conceptualized as an exercise of a court's remedial powers designed to protect those who have relied on judicial pronouncements. It is analogous to the constitutional tort cases that hold that a government actor who relies on official pronouncements will be shielded from harm if those pronouncements are in error or if the law changes. ${ }^{115}$ The relevant pronouncement in a revival case is the initial invalidating decision; the remedy is to deny enforcement of the once-unconstitutional statute unless it is repassed.

It is also possible to view prospective overruling as a choice of law doctrine, rather than as an exercise of a court's remedial powers. Under this conception of prospective overruling, courts assessing the constitutionality of a statute must decide whether to apply "new" constitutional law or "old" constitutional law; prospective overruling would involve application of the "old" law. This approach accords with that adopted by Justice O'Connor in her plurality decision in American Trucking in determining which law to apply to events that preceded the overruling decision. "In those relatively rare circumstances where established precedent is overruled," she stated, "the doctrine of nonretroactivity allows a court . . . to avoid 'jolting the expectations of parties to a transaction." "116

The argument for the choice of law approach is strongest when the "new law" reflects a judicial determination that the meaning of the Constitution has changed because of changes in societal circumstances, rather than a judicial determination that its initial holding was in error. The plurality opinion in Casey suggests that it would be possible to read

a vehicle to revisit the invalidating decision? Also, won't prospective overruling deny legislatures the means they need to signal the courts that a particular statute enjoys current majoritarian support? The answer to this argument is that the possibility of prospective overruling gives those who oppose an invalidating decision adequate incentive and opportunity to engage in such dialogue with the judiciary. By passing a statute that is unenforceable under the invalidating decision, the legislature can provide the court with the opportunity to overrule its invalidating decision. Even if the "unconstitutional" statute has to be repassed after the overturning decision to be enforceable, there is a strong reason for its proponents to pass it, because it provides a vehicle for reversal.

115. See, e.g., Mitchell v. Forsyth, 472 U.S. 511 (1985) (holding Attorney General immune from liability for authorizing warrantless wiretaps because unclear that they were unconstitutional at the time of authorization); Davis v. Scherer, 468 U.S. 183 (1984) (state officials enjoy qualified immunity unless actions violate constitutional right clearly established at time of challenged conduct); Harlow v. Fitzgerald, 457 U.S. 800 (1982) (government officials performing discretionary functions are generally shielded from liability to the extent that their actions do not violate clear constitutional or statutory rights).

116. American Trucking Ass'ns v. Smith, 496 U.S. 167, 196 (1990) (plurality opinion) (O'Connor, J.) (citation omitted); see also James B. Beam Distilling Co. v. Georgia, 111 S. Ct. 2439, 2451 (1991) (O'Connor, J., dissenting) (Chevron Oil sets forth the process by which the Supreme Court determines "whether the new law or the old is to apply to conduct occurring before the law-changing decision"). 
the Court's decision in Brown v. Board of Education, ${ }^{117}$ overruling Plessy $v$. Ferguson, ${ }^{118}$ in this light:

The Plessy Court considered "the underlying fallacy of the plaintiff's argument to consist in the assumption that the enforced separation of the two races stamps the colored race with a badge of inferiority. If this be so, it is not by reason of anything found in the act, but solely because the colored race chooses to put that construction upon it."

The Court in Brown addressed these facts of life by observing that whatever may have been the understanding in Plessy's time of the power of segregation to stigmatize those who were segregated with a "badge of inferiority," it was clear by 1954 that legally sanctioned segregation had just such an effect, to the point that racially separate public educational facilities were deemed inherently unequal. . . . While we think Plessy was wrong the day it was decided, we must also recognize that the Plessy Court's explanation for its decision was so clearly at odds with the facts apparent to the Court in 1954 that the decision to re-examine Plessy was on this ground alone not only justified but required. . . . In constitutional adjudication as elsewhere in life, changed circumstances may impose new obligations, and the thoughtful part of the Nation could accept each decision to overrule a prior case as a response to the Court's constitutional duty. ${ }^{119}$

If $R o e^{120}$ were ever to be overturned, a similar argument could be made. Dean Calabresi has recently suggested that Roe may be best understood as a decision that involved the protection of women as a group that had been largely excluded from the legislative process and that the Court might legitimately revise or reverse Roe if it determined that this were no longer the case. ${ }^{121}$ Thus, factual changes would be the occasion for reversing the initial decision, and the initial decision would not have been erroneous when it was made.

Our point here is not to argue for specific readings of Roe or Plessy. It is, rather, to suggest that when a decision is overruled because material societal facts have changed, the argument for nonrevival on choice of law grounds is compelling. A choice of law approach would render a statute enforceable only if it were enacted at a time when the factual preconditions for the statute to be constitutional were satisfied. Analo-

117. 347 U.S. 483 (1954).

118. 163 U.S. 537 (1896).

119. Planned Parenthood v. Casey, 112 S. Ct. 2791, 2813 (1992) (plurality opinion) (citations omitted).

120. Roe v. Wade, 410 U.S. 113 (1973).

121. See Calabresi, supra note 78 , at 146-48; see also Guido Calabresi, Ideals, Beliefs, Attitudes, and the Law 97, 99-101, 108-14 (1985) (antidiscrimination and Roe); Donald H. Regan, Rewriting Roe v. Wade, 77 Mich. L. Rev. 1569, 1618-39 (1979) (same). 
gously, when a constitutional amendment is passed that permits the legislature to adopt a statute that it could not previously adopt, the case law has consistently indicated that-unless the amendment is intended to be retroactive-a statute that was unconstitutional prior to the amendment will be enforceable only if it is repassed after the amendment is ratified. ${ }^{122}$ Specifically, in the leading case on point, Newberry $v$. United States, ${ }^{123}$ the Supreme Court found that a subsequently passed constitutional amendment would not make a statute that predated the amendment constitutional because "[a]n after-acquired power can not ex proprio vigore validate a statute void when enacted." 124 Here, the same principle would be applied when it is the meaning of the Constitution, rather than one of its component elements, that changes: the legislature cannot pass a statute that exceeds its powers; if the meaning of the Constitution changes so that the powers of the legislature expand, legislation once beyond the legislature's scope but now permissible must be repassed to be enforceable.

In the limited context discussed above, the choice of law approach is based on the idea that the meaning of the Constitution changes as society changes. Generally, however, the choice of law approach necessarily (if implicitly) rests on the idea that the Constitution means simply what the judiciary says it means. When the judiciary changes its mind,

122. See, e.g., Newberry v. United States, 256 U.S. 232, 254 (1921) (Seventeenth Amendment could not validate section 8 of Federal Corrupt Practices Act, which was void when enacted); Banaz v. Smith, 65 P. 309, 310 (Ca. 1901) (unless expressly provided, a state constitutional amendment cannot give life to void provisions in a city charter); Grayson-Robinson Stores v. Oneida, Ltd., 75 S.E.2d 161, 164 (Ga. 1953), cert. denied, 346 U.S. 823 (1953) (citing with approval cases holding that a constitutional amendment cannot validate a previously enacted statute); Dullam v. Willson, 19 N.W. 112,114 (Mich. 1884) (a statute that was held unconstitutional and thus void could not empower the Governor to remove an institute trustee even after the constitution had been amended lifting the original objection); State ex rel. Rogers v. Swanson, 219 N.W.2d 726, 729 (Neb. 1974) (statute authorizing tuition grants for private school attendance was invalid when passed and could not be revived by a constitutional amendment regardless of whether that amendment might authorize such action); see also Norman J. Singer, Statutes and Statutory Construction $\S 2.07$, at 37 (rev. ed. 1985) (stating rule). The amendment, however, need not explicitly state that it is to have retroactive effect, so long as the intent to have such an effect is apparent. For example, the Fourteenth Amendment was passed, among other reasons, to establish a clear constitutional basis for the previously enacted Civil Rights Act of 1866. See William E. Nelson, The Fourteenth Amendment: From Political Principle to Judicial Doctrine 104 (1988) (arguing that section 1 of the Fourteenth Amendment was added in part for this purpose); Robert J. Kaczorowski, Revolutionary Constitutionalism in the Era of the Civil War and Reconstruction, 61 N.Y.U. L. Rev. 863, 910 (1986) (observing that "congressional Republicans . . . acted to incorporate the Civil Rights Act into the Constitution through the first section of the fourteenth amendment"); see a $\rightarrow$ Akhil R. Amar, The Bill of Rights and the Fourteenth Amendment, 101 Yale L.J. 1193, 1244-46 (1992) (discussing the relationship between the Fourteenth Amendment and the Civil Rights Act of 1866).

123. 256 U.S. 234 (1921).

124. Id. at 254. 
the meaning of the Constitution changes. The most profound critique of prospective overruling-Justice Harlan's dissenting opinion in Desist v. United States ${ }^{125}$ and his dissenting and concurring opinion in Mackey v. United States ${ }^{126}$-was based on the notion that this view of judicial law making is illegitimate. ${ }^{127}$ This critique is even more compelling in the

125. 394 U.S. 244, 256-69 (1969) (Harlan, J., dissenting). Justice Harlan's view was subsequently endorsed by the Court in Griffith v. Kentucky, 479 U.S. 314, 322-29 (1987) (citing Justice Harlan's position in Desist).

126. 401 U.S. 667, 675-702 (1971) (Harlan, J., concurring in part and dissenting in part).

127. Concern that prospective overruling amounts to judicial law making animates one part of the current Court and helps explain the Court's inconsistent application of prospective overruling. For example, this concern played an important role in the Court's decision in Griffith to overturn Stovall and apply new law retroactively in criminal cases on direct review. For the liberals on the Court, the result in Griffith was desirable primarily because the decision guaranteed equal treatment of similarly situated defendants. Justices Scalia and Powell joined the majority because they equated prospective overruling with judicial law making. See Fallon \& Meltzer, supra note 58, at 1745 .

This concern also helps explain the complicated result in James B. Beam Distilling Co. v. Georgia, 111 S. Ct. 2439 (1991). At issue was whether a new rule of law, if it was applied in the case in which the new rule was announced, had to be applied retroactively to all other cases. In other words, the case presented the question of whether selective prospectivity in civil cases was legitimate. The three dissenters-Justices O'Connor and Kennedy and Chief Justice Rehnquist-urged the choice of law analysis discussed above and contended that the fact that the new rule had been applied in the case in which it was announced did not mean that it had to be applied in all other cases. See id. at 2451 (O'Connor, J., dissenting). The majority held that full retroactivity was necessary, but did so for a range of reasons. Justices Souter and Stevens found that the need for equal treatment of similarly situated parties required full retroactivity, but they did not challenge the legitimacy of full prospectivity. See id. at 2441-48 (Souter, J., with one Justice joining the opinion and four Justices concurring in the judgment). (The previous year Justice Stevens had endorsed prospective overruling as an appropriate constitutional remedy. See American Trucking Ass'ns v. Smith, 496 U.S. 167, 223 (1990) (Stevens, J., dissenting).) Justice White concurred on the grounds that there was "no precedent in civil cases [for] applying a new rule to the parties in the case but not to others similarly situated." James B. Beam Distilling Co., 111 S. Ct. at 2448 (White, J., concurring). He specifically stated, however, that courts could prospectively overrule their precedent, so long as they did not apply the new rule of law to the party in the case where the new rule was announced. See id. at 2449. Justices Blackmun, Scalia, and Marshall concurred on the grounds that prospective overruling was always illegitimate judicial law making. See id. at 2449-50 (Blackmun, J., concurring); id. at 2450-51 (Scalia, J., concurring).

Finally, that concern was present in the majority opinion and in Justice Scalia's concurrence in Harper v. Virginia Dep't of Taxation, 113 S. Ct. 2510 (1993), the Court's most recent confrontation with the prospective overruling question. The Court in Harper rejected selective prospectivity in civil cases, suggesting that it was a " 'legislat[ive]' prerogative" to determine that a new rule of law should be applied only prospectively. See id. at 2516 (quoting Griffith v. Kentucky, 479 U.S. 314, 322 (1987)). Indeed, dicta in the majority opinion suggest that a new rule of a federal law must be applied retroactively. See, e.g., id. at 2516 ("basic norms of constitutional adjudication" inform rejection of prospectivity in criminal context) (citation omitted); id. at 2517 (absence of "constitutional authority . . . to disregard current law"). But see id. at 
context of prospective overruling when applied to statutes, as opposed to events. In the statutory context, prospective overruling based on choice of law notions would mean that a judicial decision that the court subsequently decided to overturn would nonetheless provide a basis for judicial invalidation of a statute that the legislature had passed in accordance with its view of the Constitution. Such a result necessarily implies that the judiciary alone has the power to determine what the Constitution means. Indeed, it implies that the judiciary's errors can trump legislative views of the Constitution that the judiciary subsequently determines were correct. Such an expansive view of the judicial role is inconsistent with our constitutional heritage, beginning with Marbury v. Madison. ${ }^{128}$

Viewing prospective overruling as a remedy, however, does not in-

2527-28 (O'Connor, J., dissenting) (countering implication in majority opinion that it is improper to give new rule of law only prospective application with citation to cases in which new rules were given purely prospective effect). Justice Scalia (who, in addition to filing a concurrence, was one of the five votes making up the majority) similarly concluded that the decision to make a new rule of law operate only prospectively was legislative, rather than judicial, in nature. See id. at 2520-24.

The response to this critique is set forth in the text: if prospective overruling is conceptualized as a remedy, then it does not involve judicial law-making; it involves, instead, the exercise of a traditional judicial function. See infra notes 129-132 and accompanying text.

128. 5 U.S. (1 Cranch) 137 (1803). The relevant scholarly literature is vast, but for leading examples of academic thought expounding on the principle that in our system of judicial review, beginning with Marbury, the judiciary is not the sole authoritative source of constitutional interpretation, see, e.g., Alexander M. Bickel, The Least Dangerous Branch 263-64 (1962) (discussing the view that Congress should not enact a bill it considers unconstitutional); Robert L. Clinton, Marbury v. Madison and Judicial Review 98-99 (1989) (arguing that Marbury does not attribute exclusive power to interpret the Constitution to the Court and does not deny the legislative power to engage in constitutional interpretation); Laurence H. Tribe, American Constitutional Law 23-42 (2d ed. 1988) (arguing that "a variety of actors" possess the power to interpret the Constitutic $\rightarrow$ Gerald Gunther, The Subtle Vices of the "Passive Virtues"-A Comment on Principle and Expediency in Judicial Review, 64 Colum. L. Rev. 1, 25 n.155 (1964) (pointing out that Marshall's assertion of judicial authority to interpret the Constitution in Marbury does not stand for judicial exclusiveness in constitutional interpretation);

$\rightarrow$ Herbert Wechsler, The Courts and the Constitution, 65 Colum. L. Rev. 1001, 1008 (1965) (quoting Lincoln's First Inaugural address as an example of the view that the policy of the government is not determined by the Court's decisions). For examples of the competing scholarly view, holding that Marbury embodies the position that the Constitution means what the Court interprets it to mean and nothing more, see, e.g., Edmond Cahn, An American Contribution in Supreme Court and Supreme Law 1, 25 (Edmond Cahn ed., 1954) (Marbury begins a "colloquy" between Court and people in which the Court asserts, "You live under a Constitution but the Constitution is what we say it is. ..."); Benjamin F. Wright, The Growth of American Constitutional Laws 37 (1967) ("[Marbury reflects] a theory of the judges as the only true guardians of the permanent will of the people which is incorporated in the Constitution"). The Supreme Court opinion which arguably asserts absolute judicial supremacy in constitutional interpretation is Cooper v. Aaron, 358 U.S. 1, 18 (1958) (declaring that "the federal judiciary is supreme in the exposition of the law of the Constitution"). For a defense of this approach, see Daniel A. Farber, The Supreme Court and the Rule of Law: Cooper $r$. 
volve accepting such a broad judicial role. Seen in this light, prospective overruling does not imply that a statute once held unconstitutional was in fact unconstitutional, even though the Court subsequently determined that the initial judgment of invalidity was wrong. To support prospective overruling as a remedy is to make the much lesser claim that, when a court changes its mind about a rule of constitutional law, it can take the steps needed to protect those who relied on its initial determination.

Conceiving of prospective overruling as a remedy is hardly novel. Writing for four dissenters in American Trucking, Justice Stevens proposed treating prospective overruling as part of the law of remedies designed to protect reliance. ${ }^{129}$ The idea can be traced back to Justice Harlan, ${ }^{130}$ and it has recently been convincingly argued for by Professors Fallon and Meltzer. ${ }^{131}$

When viewed as a remedy, the technique of prospective overruling is concerned with the consequences that should follow from the relative unpredictability of a judicial decision that overturns a previous judicial decision. ${ }^{132}$ With respect to statutes, one problem associated with relative unpredictability is political reliance. Political actors allocate their political capital based on the assumption that the initial judicial decision is unlikely to be overturned. If political reliance with respect to a specific statute is sufficiently compelling to justify shaping a judicial remedy, only one remedy appears adequate: denying enforcement of the previously unconstitutional statute unless it is repassed. No other remedy will avoid seriously disadvantaging those who relied on the initial invalidating decision.

But should courts be able to engage in selective prospectivity? That is, if a court in the overruling decision evaluates a statute under the rule of law announced in that decision, must all other statutes be evaluated using that new rule of law-or can the old rule of law be applied in other cases? ${ }^{133}$ These questions appear particularly significant in the wake of Casey, since the Court there applied the new rule of law to the Pennsylvania statute at issue in the case. Thus, if there is no selective prospective overruling in the statutory context, the rule of law enunciated in Casey, having been applied to one statute, is applicable to all other statutes on the books.

Although the Supreme Court once sanctioned selective prospectiv-

Aaron Revisited, 1982 U. Ill. L. Rev. 387, 403-11. But see Tribe, supra, at 35 (arguing that Cooper need not be read as embodying such a broad assertion of judicial authority).

129. See 496 U.S. at 221-24 (Stevens, J., dissenting).

130. See United States v. Estate of Donnelly, 397 U.S. 286, 296-97 (1970) (Harlan, J., concurring); see also 496 U.S. at 223-24 (Stevens, J., dissenting) (citing concurring opinion of Justice Harlan in Estate of Donnelly as support for view of prospective overruling as remedy).

131. See Fallon \& Meltzer, supra note 58, at 1758-77.

132. See id. at 1768 .

133. For further discussion of this doctrine, see supra note 127. 
ity in criminal cases, ${ }^{134}$ more recently, it has rejected this doctrine, finding that it violates the principle of treating like cases alike. ${ }^{135}$ The Court has never applied selective prospectivity in the civil context, and in the recent case of Harper $v$. Virginia Department of Taxation, ${ }^{136}$ it specifically rejected the doctrine. There appears to be a two-fold rationale for that decision. First, the Court in Harper suggested that only legislatures properly have the freedom "to make rules of law retroactive or prospective as [they] see fit"; ${ }^{137}$ the nature of the judicial function requires retroactive application of new rules. ${ }^{138}$ Second, " 'selective application of new rules violates the principle of treating similarly situated [parties] the same." "139

But if prospective overruling is viewed as remedial, the court that adopts it is not, in fact, usurping legislative functions; it is merely deciding, as is consistent with judicial practice in a range of other contexts, to fashion a remedy capable of protecting those who have relied on its decisions. Moreover, the risk of treating similar cases disparately does not arise when prospective overruling is applied to statutes. Similarly situated litigants will receive the same treatment so long as the application of a particular statute is consistent. ${ }^{140}$

134. See Daniel v. Louisiana, 420 U.S. 31, 32-33 (1975); Stovall v. Denno, 388 U.S. 293, 296-301 (1967); Johnson v. New Jersey, 384 U.S. 719, 726-35 (1966).

135. See Griffith v. Kentucky, 479 U.S. 314, 327-28 (1987) ("actual inequity . . . results when only one of many similarly situated defendants receives the benefit of the new rule" (citation omitted)).

136. 113 S. Ct. 2510 (1993).

137. Id. at 2516.

138. This argument suggests that a rule of pure prospectivity would also be illegitimate. See supra note 127.

139. 113 S. Ct. at 2516 (quoting Griffth, 479 U.S. at 323).

140. In addition, the reliance interest will vary from statute to statute and thus it is appropriate to treat some litigants differently from others. For example, as will be subsequently discussed (see infra part II.D), the reliance interest for a post-Webster abortion statute would not be the same as with a pre-Webster statute. Courts thus should have the ability to apply the new rule of law to some, but not all, statutes passed prior to its announcement. This would not violate the principle of treating similarly situated things alike since from the relevant perspective-that of the degree of reliance-not all statutes are similarly situated. Thus, the better view is that the fact that the statute in Casey is now enforceable should not mean that other abortion regulation statutes that satisfy the Casey test will be enforceable without being repassed. Moreover, if courts were to adopt the doctrine of prospective overruling in the statutory context, there would be a particularly compelling case for not holding that failure to apply that doctrine in Casey would bar application of this technique to other abortion statutes. Not only was the technique not considered in Casey, the technique had not even been advanced as a theory at that time. Under these circumstances, it is clear that the Court did not make a considered choice not to overrule the statute prospectively. Thus, the Casey situation is different from that in Harper. The Court in the overruling decision that preceded Harper, Davis v. Michigan Dep't of the Treasury, 489 U.S. 803 (1989), had available to it the doctrine of prospective overruling and elected not to apply it. See Harper, 113 S. Ct. at 2513-16 (discussing Davis). 


\section{Determining When to Overrule Statutes Prospectively}

Expanding the doctrine of prospective overruling would not require judging all statutes passed prior to the judiciary's promulgation of a new rule by the old rule. The Chevron Oil test-which the Court has enunciated as its guide in determining when prospective overruling is called for ${ }^{141}$-remains an appropriate guide as the doctrine of prospective overruling is extended to the statutory context. Because of the political reliance problem, in evaluating statutes, the critical prong of the Chevron Oil test is the third one: "[w]here a decision of this Court could produce substantial inequitable results if applied retroactively, there is ample basis in our cases for avoiding the 'injustice or hardship' by a holding of nonretroactivity." 142 Whether "injustice or hardship" mandate prospective application will turn on a fact-specific inquiry; we propose that this inquiry take into account three factors.

The first factor to be considered is the amount of time that elapsed between the invalidating decision and the overruling decision. The greater the passage of time, the more likely it is that political actors have relied on the finality of the judicial decision. For example, the case for political reliance is particularly compelling with respect to the Civil Rights Act of 1875 since more than one hundred years have passed since the Act was invalidated. In contrast, if the Supreme Court overturns a statute and then reverses itself the following month, the case for political reliance is unpersuasive. Hepburn ${ }^{143}$ and the Legal Tender Cases ${ }^{144}$ exemplify this situation. Hepburn was decided on February 7, 1870; on March 25, 1870, the Attorney General asked the Court to hear another legal tender case in order to reconsider its decision; on April 1, 1870, the Court acceded to that request, agreeing to hear the Legal Tender Cases. ${ }^{145}$

The second factor to be considered concerns the extent to which it was clear that the statute at issue was unconstitutional under the invalidating decision. If the statute at issue was the statute involved in the invalidating decision, then the answer is obvious. For example, Roe concerned Texas's criminal abortion statute; there could be no question that that statute was unconstitutional under the rule of law enunciated in Roe-since that was the express holding of the Court. ${ }^{146}$ It can also be clear, however, that statutes other than those explicitly and directly at issue in the invalidating decision were unconstitutional under

141. See supra notes 105-108 and accompanying text.

142. Chevron Oil Co. v. Huson, 404 U.S. 97, 107 (1971) (citations omitted).

143. Hepburn v. Griswold, 75 U.S. (8 Wall.) 603 (1870). See discussion supra notes 32-39 and accompanying text.

144. Legal Tender Cases, 79 U.S. (12 Wall.) 457 (1871). See discussion supra notes 32-39 and accompanying text.

145. $\mathrm{S} \rightarrow$ Charles Fairman, Mr. Justice Bradley's Appointment to the Supreme Court and the Legal Tender Cases (Installment 2), 54 Harv. L. Rev. 1128, 1128 (1941).

146. Roe v. Wade, 410 U.S. 113, 164 (1973). 
the rule of law that decision established. For example, it is apparent that, under the rule established in Roe, statutes that criminalize any abortion except an abortion to save the mother's life are unconstitutional. Roe says as much. ${ }^{147}$ In contrast, the more the invalidating decision is ambiguous or its contours unclear, the less the equities favor political actors who assumed that the statute was unconstitutional.

The third factor is the relative timing of the statute's passage and the relevant judicial decisions. As previously discussed, an invalidating decision skews the political dynamic. A statute passed prior to the invalidating decision may not be repealed after that decision despite the fact that it no longer has majoritarian support. Similarly, a statute may be passed after the invalidating decision even though it does not enjoy majoritarian support. When a court, however, signals that it is reconsidering an invalidating decision, then the political process is no longer skewed: political actors know, or should know, that a statute they pass-even though invalid under current case law-may be upheld. In such circumstances, political reliance is unlikely to exist, and, if it does exist, should not be rewarded. To take a concrete example: Webster altered the relevant political context, for five members of the Court arguably signalled (albeit in different ways) that Roe was in danger of being overruled. ${ }^{148}$ Webster, therefore, placed political actors on notice that they could not rely on Roe. Political developments reflected the change in judicial climate: as previously noted, after Webster, the number of state legislative bodies that supported keeping abortion legal rose from twenty-three to fifty. ${ }^{149}$

This analysis suggests the following typology. Let us call Adams the invalidating decision; Baker the decision that signals that a court is reconsidering Adams; Cobb the decision that overrules Adams. The third factor that we have identified as relevant to the determination of whether there has been political reliance meriting protection would counsel that, after $C o b b$, statutes inconsistent with the rule in Adams and which were passed prior to Adams would have to be repassed to be enforceable. The same is true of statutes passed between Adams and $B a k e r$. But post-Baker and pre-Cobb statutes would not have to be repassed to be enforceable. Prospective overruling would thus effectively serve to protect political reliance, ensuring that those who take judicial decisions seriously and structure their political activities in accordance

147. "A state criminal abortion statute of the current Texas type, that excepts from criminality only a life-saving procedure on behalf of the mother, without regard to pregnancy stage and without recognition of the other interests involved, is violative of the Due Process Clause of the Fourteenth Amendment." Id.

148. See Webster v. Reproductive Health Servs., 492 U.S. 490, 521 (1989) (threemember plurality opinion); id. at 525-26 (O’Connor, J., concurring); id. at 532 (Scalia, J., concurring).

149. See supra note 77 and accompanying text. 
with such decisions will not be harmed when a court alters its constitutional interpretation.

\section{Current Majorities}

Part II of this Article argued that prospective overruling is appropriate in certain circumstances in which political reliance on an invalidating decision has skewed the operation of majoritarian decisionmaking processes. This Part presents a second theoretical justification for the doctrine of prospective overruling of statutes, and a second category of cases in which use of the doctrine is appropriate. Our argument here draws on the insights of Alexander Bickel in his Harvard Foreword, The Passive Virtues. In that essay, Bickel highlighted the fact that a statute may remain on the books even if it does not enjoy the support of a current majority, and he argued that courts should use technical devices to force current majoritarian consideration of constitutionally problematic statutes. Our first subpart develops both Bickel's ideas and the principal criticisms leveled against the Bickelian approach. Our second subpart applies Bickel's ideas to the revival debate. We argue that prospective overruling lacks the weaknesses of the judicial tools that Bickel urged courts to apply. More importantly, Bickel's arguments make it clear that there is one class of statutes for which prospective overruling is particularly appropriate: statutes that affect individual liberty. If a statute is found unconstitutional on the grounds that it violates individual liberty (or if it is unconstitutional under a rule of law enunciated in decisions concerning liberty interests), it clearly affects constitutionally protected liberty interests, even though a subsequent judicial decision may establish a new rule of law under which the statute's affect on liberty interests would no longer be held to rise to the level of unconstitutionality. The importance our constitutional system attaches to the protection of individual liberty indicates that such a statute should be enforceable only if a current majority, made aware of the relevant constitutional concerns by both the invalidating decision and the overruling decision, reaffirms its desire for that statute.

\section{A. The Past Majoritarian Dilemma and Bickel}

In both our national and state systems, in order to be adopted legislation must go through a process that ensures that it has majoritarian, if not supermajoritarian, support. Thus, in the federal government (and most of the states), to become law the proposed statute must navigate a committee structure that has the capacity to prevent its further consideration; it must secure passage by both legislative houses; and, in the event of an executive veto, it must garner enough support to override the veto. ${ }^{150}$ 
But once a statute is on the books, the "burden of inertia," 151 to use Guido Calabresi's phrase, is on its side. A combination of thirtyfour percent of one house of the legislature and the executive is obviously sufficient to keep the statute on the books, even if it lacks current majoritarian support. Indeed, the committee system is such that a far weaker coalition can block repeal. And so a "revived" abortion statute, for example, may remain in force despite current majoritarian desires. ${ }^{152}$

Yet the commitment of our system of government to majority rule raises the question: Why should the starting point of legislation reflect the beliefs of past, rather than current, majorities? There are, of course, reasons why, in the normal course of affairs, legislation does not automatically expire. Legislative energy is a scarce resource whose consequences should not be lightly cast aside. ${ }^{153}$ Moreover, the incentives to pass legislation would be radically undercut if all legislation were temporary, and proposed legislation would not receive the attention it requires. But perhaps most important, with the ordinary statute, its ongoing enforcement, combined with the fact that it has not been repealed, indicates that it has continuously enjoyed some level of support. At no point has the majority decided that the statute is both of such significance and so erroneous or counterproductive as to warrant the expenditure of efforts necessary to repeal it.

The issue of the extent to which old majorities should be able to establish the starting point for current deliberations has been one that Americans have debated since at least the time of the ratification debates over the Constitution. Anti-federalists, for example, opposed the Constitution in part on the grounds that its flexibility and purported ability to adapt to the future was a weakness, not a strength. They claimed that the dead hand control that the Constitution represented would unfairly burden future generations; better to have a time-bound constitution that would be repealed, rather than one that sought to constrain governmental decision-making for all time. ${ }^{154}$ Even propo-

coalition can be formed in support of a statute comprising both those who actually favor it and those who are willing to endorse it in exchange for support on other matters from the statute's actual proponents. See Daniel A. Farber, Statutory Interpretation and Legislative Supremacy, 78 Geo. L.J. 281, 308-09 nn.140-41 (1989); see a $\rightarrow$ Akhil R. Amar, Philadelphia Revisited: Amending the Constitution Outside Article V, 55 U. Chi. L. Rev. 1043, 1083-85 (1988) (less representative Senate can exploit leverage to secure House support for statute).

151. Guido Calabresi, A Common Law for the Age of Statutes 164 (1982).

152. This is equally true whether the current majority desires a statute that is more restrictive (assuming it is still within constitutional bounds) or less restrictive than the revived statute.

153. See Hutchinson \& Morgan, supra note 64, at 1765 (discussing scarcity of legislative time and consequences of that scarcity).

154. See Michael Lienesch, New Order of the Ages: Time, The Constitution, and the Making of Modern American Political Thought 148-50 (1988) (discussing anti- 
nents of the Constitution were concerned about this issue. Thus, Thomas Jefferson wrote James Madison:

$[\mathrm{N}]$ o society can make a perpetual constitution, or even a perpetual law. The earth belongs always to the living generation. They may manage it then, and what proceeds from it, as they please, during their usufruct. They are masters too of their own persons, and consequently may govern them as they please. But persons and property make the sum of the objects of government. The constitution and the laws of their predecessors extinguished then in their natural course with those who gave them being. This could preserve that being till it ceased to be itself, and no longer. Every constitution then, and every law, naturally expires at the end of 19 years. If it be enforced longer, it is an act of force, and not of right. ${ }^{155}$

Such concerns reemerged in modern legal scholarship through the work of Alexander Bickel, and in particular his Harvard Foreword, The Passive Virtues. ${ }^{156}$ The Passive Virtues reflects Bickel's belief that, as a general matter, current majorities have a superior claim to authority in a democracy than past majorities. The Passive Virtues also advances the related argument that, in constitutional gray areas courts should promote informed current majoritarian decision-making by forcing considered majoritarian reevaluation of legislation, rather than simply holding it unconstitutional. ${ }^{157}$

The section of The Passive Virtues of greatest relevance to the revival debate is Bickel's discussion of the Supreme Court's decision in Poe v. Ullman. ${ }^{158}$ At issue in Poe was the constitutionality of Connecticut's birth control statute, which made it a misdemeanor for a person to use "any drug, medicinal article or instrument for the purpose of preventing conception." 159 Those who sold or distributed birth control devices could be punished as accessories to a crime. ${ }^{160}$

The birth control statute had been passed in $1879 .{ }^{161}$ In the more than three-quarters of a century between the time of the Act's passage

federalist concern that a constitution articulated in broad and flexible language would invite oppression).

155. Letter from Thomas Jefferson to James Madison (Sept. 6, 1789), in 15 The Papers of Thomas Jefferson 392, 395-96 (Julian Boyd ed., 1958). For a recent intellectual history of this letter, see Herbert Sloan, "The Earth Belongs in Usufruct to the Living," in Jeffersonian Legacies 281 (Peter S. Onuf ed., 1993).

156. See Bickel, supra note 22.

157. Bickel's principal works are: The Least Dangerous Branch (1962); The Morality of Consent (1975); Politics and the Warren Court (1965); The Supreme Court and the Idea of Progress (1970); The Supreme Court, 1960 Term-Foreword: The Passive Virtues, 75 Harv. L. Rev. 40 (1961); and, with Harry H. Wellington, Legislative Purpose and the Judicial Process: The Lincoln Mills Case, 71 Harv. L. Rev. 1 (1957).

158. 367 U.S. 497 (1961).

159. Conn. Gen. Stat. § 53-32 (1958).

160. See id. §54-196.

161. See Bickel, supra note 22 , at $61 \&$ n.98. 
and the Supreme Court's consideration of it, practically no one similarly situated to appellants-two women whose lives would be endangered by child bearing, the husband of one of the two women, and the doctor who wished to advise them on birth control-had been prosecuted under the statute. ${ }^{162}$

In Bickel's view, the lack of enforcement suggested that the bill no longer had current majoritarian support. "The influences that favor the objective of the statute cannot summon sufficient political strength-or perhaps they have not the desire-to cause it to be enforced; assuming that the consistent enforcement of a law is as much a function of the political process as is enactment of it."163 Nonenforcement was relevant to Bickel because it suggested that relatively little weight should be given to the fact that there had not been repeal. He wrote:

It would be foolish, of course, and it would ensure paralysis, to expect continual expression of the legislative will through continual reconsideration of the statutebook. But normal law enforcement indicates the continuity of will, because it conduces to legislative reconsideration when the dominant opinion turns-although greater strength must be mobilized to repeal a statute than to resist its enactment. When the law is consistently not enforced, the chance of mustering opposition sufficient to move the legislature is reduced to the vanishing point. ${ }^{164}$

At the same time, the pro-birth control forces had not been able to achieve the end they desired: "The influences which oppose the law cannot summon sufficient political strength to cause it to be repealed; attempts have been made from 1923 onward, and they have failed." 165 " $[\mathrm{T}]$ he statute does not speak the present will of dominant forces in the state," Bickel wrote, "[i]t represents at present a deadlock of wills, from which the Court was asked to extricate the state."166

The Court in Poe dismissed the case. Justice Frankfurter's plurality opinion found the plaintiffs lacked standing to sue. ${ }^{167}$ In support of this conclusion, Frankfurter stressed the prudential aspect of the Supreme Court's standing doctrine, ${ }^{168}$ and noted that " $[\mathrm{t}]$ he undeviating policy of nullification by Connecticut of its anti-contraceptive laws throughout all the long years that they have been on the statute books bespeaks more than prosecutorial paralysis." 169

Bickel interpreted the case, and in particular Frankfurter's refer-

162. See id. at 59-61.

163. Id. at 60 (footnote omitted).

164. Id. at 63 .

165. Id. at 60 .

166. Id. at 61 .

167. See Poe v. Ullman, 367 U.S. 497, 508-09 (1961) (plurality opinion).

168. See id. at 503.

169. Id. at 502 . 
ences to nonenforcement, as standing for the proposition that had the appellants in the case been prosecuted, as opposed to seeking a declaratory judgment, the Supreme Court would have held that the prosecution "would fail on the grounds of desuetude."170 Desuetude (as conceptualized by Bickel) stood for the proposition that "a statute that has never been enforced and that has not been obeyed for threequarters of a century may [not] suddenly be resurrected and applied." 171 The doctrine was appropriate because "[ $t]$ he unenforced statute is not, in the normal way, a continuing reflection of the balance of political pressures. When it is resurrected and enforced, it represents the ad hoc decision of the prosecutor, unrelated to anything that may realistically be taken as present legislative policy."172

Poe did not stand for the proposition that Connecticut's birth control statute was unconstitutional, nor did it stand for the proposition that the statute was constitutional. Rather, it stood for the proposition that, before the Court would rule on the statute's constitutional merits, it wanted a considered judgment by a contemporary legislature that the statute should be enforced. As Bickel put it:

The Court in the Birth Control Cases engaged in a sort of colloquy with the political institutions, begun by way of questions and answers at the [oral] argument, stylized and brought to a Socratic conclusion in the prevailing opinion. The upshot was the framing of conditions to invite a responsible legislative decision. ${ }^{173}$

More broadly, Bickel argued that courts should not be forced to choose between invalidating and upholding statutes. ${ }^{174}$ Seeking a middle ground that permitted courts to engage in constitutional education without unnecessarily weakening majoritarian power, he argued that they should instead exploit various procedural devices to highlight for the legislature particular acts that were in constitutional gray areas. In addition to desuetude, Bickel suggested that the doctrines of delegation of powers, ripeness, standing, and void for vagueness could be used to this end.

Bickel's The Passive Virtues essay in general, as well as his use of the doctrine of desuetude, has evoked passionate criticism, with the most telling critique offered by Professor Gerald Gunther. ${ }^{175}$ Gunther attacked Bickel's reading of Poe, describing his use of the doctrine of desuetude as "novel and tenuous." 176 Gunther also attacked Bickel for

170. Bickel, supra note 22 , at 64 .

171. Id. at 62 .

172. Id. at 63 .

173. Id. at 64 .

174. This view has come to be known as the passive virtues doctrine.

175. See Gunther, supra note 128.

176. Id. at 20. For more detailed critiques of Bickel's desuetude argument, see Linda Rogers \& William Rogers, Desuetude as a Defense, 52 Iowa L. Rev. 1, 2-29 (1966) (rejecting doctrine of desuetud $\rightarrow$ Mark P. Henriques, Note, Desuetude and 
urging the Court to exploit technical devices to avoid deciding difficult questions of constitutional law. Employing particularly memorable phrasing, Gunther observed: "There indeed lies the novelty and vulnerability of the Bickel thesis: the emphasis on principle as the highest Court duty, but only in a limited sphere of Court actions; the $100 \%$ insistence on principle, $20 \%$ of the time." 177

According to Gunther, the avoidance techniques that Bickel discussed in his article had precedentially established meanings. Bickel, however, was redefining them in order to give the Court the freedom to decide the constitutional cases it wanted to decide, and the ability to force legislative reconsideration when it thought that approach appropriate. ${ }^{178}$ Thus, while Bickel claimed to be an advocate of judicial restraint, he had developed an approach to constitutional law that would result in a "virulent variety of free-wheeling interventionism." 179

Despite criticisms such as Gunther's, Bickel's vision has had a broad appeal for legal scholars. The notion of judicial review as constitutional dialogue-which can be found in the work of such scholars as Louis Fisher, ${ }^{180}$ Harry Wellington, ${ }^{181}$ Henry Monaghan, ${ }^{182}$ Terrance

Declaratory Judgment: A New Challenge to Obsolete Laws, 76 Va. L. Rev. 1057, 1075 (1990) (arguing that Bickel's reading of Poe was "strained" and that the doctrine of desuetude should not be exploited by courts to avoid constitutional questions). On the other hand, the West Virginia Supreme Court has recently read Poe much as Bickel did and invoked it in support of its use of desuetude to bar a criminal prosecution. See Committee on Legal Ethics v. Printz, 416 S.E.2d 720, 726-27 (W. Va. 1992) (describing desuetude as a widely accepted-if seldom applied-legal concept based on notions of fairness embodied in the Due Process and Equal Protection Clauses). We are indebted to Professor Joseph Perillo for this reference.

177. Gunther, supra note 128 , at 3.

178. See id. at 9-25; see also Calabresi, supra note 121, at 16-21 (advancing a similar criticism of Bickel).

179. Gunther, supra note 128 , at 25.

180. See Louis Fisher, Constitutional Dialogues: Interpretation as Political Process 3-6, 85-118 (1988) (advancing the theory that the three branches of government interact in an ongoing colloquy over constitutional law).

181. See Harry H. Wellington, Common Law Rules and Constitutional Double Standards: Some Notes on Adjudication, 83 Yale L.J. 221, 265-311 (1973) (examining the allocation of responsibility for constitutional law making between the legislative and judicial branch $\rightarrow$ Harry H. Wellington, The Nature of Judicial Review, 91 Yale L.J. 486, 504-20 (1982) (examining the effect of judicial review on the more majoritarian branches' tendency to articulate their goals precisely and clear $\rightarrow$ Harry $\mathrm{H}$. Wellington, Book Review, 97 Harv. L. Rev. 326, 333-35 (1983) (reviewing Michael J. Perry, The Constitution, the Courts, and Human Rights (1982) (urging legislative-judicial dialogue on constitutional questions)).

182. S $\rightarrow$ Henry P. Monaghan, The Supreme Court, 1974 Term-Foreword: Constitutional Common Law, 89 Harv. L. Rev. 1, 26-30 (1975) (suggesting that the creation of a federal common law regarding civil liberties provides the Court with a means for "involving the Congress in a continuing process of defining the context and consequences of individual liberties" thereby instituting a dialogue between the Court and the Congress). 
Sandalow, ${ }^{183}$ and Paul Dimond ${ }^{184}$-ultimately rests on the Bickelian premise that a primary role of courts in constitutional adjudication is to force legislatures to focus on the constitutional consequences of their acts. As Dimond has explained the concept of constitutional dialogue:

[T] he Court itself may choose to invoke a variety of devices ... to kick a particular policy issue back to the legislature for reconsideration. Such judicial actions merely operate as suspensive vetoes and invite the people's elected representatives to reconsider the issue again and legislate more carefully and directly on the subject matter if they so choose. . . .

The Court's rulings may take the form of final interpretations and at any point appear to be forever binding. Over time, however, they can be better understood as positing a provisional meaning, which will be followed, supplemented, expanded, eroded, distinguished, ignored, or reversed as the people and future Courts respond. ${ }^{185}$

Bickel's concern with vindicating current majorities has received its greatest elaboration in Guido Calabresi's A Common Law for the Age of Statutes, where it is applied outside of the constitutional context. Calabresi started from the premise that American society was "choking on obsolete statutes." 186 Because of societal change, and in particular because of the development of the regulatory state, this country had witnessed an " 'orgy of statute making." "187 The common law had permitted courts to update the law to reflect societal and legal change. But statutory law had no such capacity for judicial updating. The legislative process was subject to what Calabresi called a "retentionist bias," 188 which prevented legislative repeal or revision, even as majoritarian support for legislation disappeared.

According to Calabresi, the need for change was not being met. "Although abrupt or frequent changes are often not desirable," he wrote, "laws must change to meet the needs of changing times and, in democratic systems, the demands of changing majorities or, perhaps more accurately, of changing coalitions of minorities." 189 This was not

183. See Terrance Sandalow, Judicial Protection of Minorities, 75 Mich. L. Rev. $1162,1187-90$ (1977) (By exercising constitutional review, courts "help ensure that the effective delegations of power required in a complex society do not lead to governmental action that departs from the society's fundamental values.").

184. See Paul R. Dimond, The Supreme Court and Judicial Choice: The Role of Provisional Review in a Democracy 11-20, 153-56 $(19 \varepsilon \rightarrow$ Paul R. Dimond, Common Sense About an Uncommon Rejection, 15 Law \& Soc. Inquiry 767, 798 (1990) [hereinafter Dimond, Common Sense] (reviewing Robert H. Bork, The Tempting of America: The Political Seduction of the Law (1990) \& Ethan Bronner, Battle for Justice: How the Bork Nomination Shook America (1989)).

185. Dimond, Common Sense, supra note 184, at 798 (footnotes omitted).

186. Calabresi, supra note 151 , at 169 .

187. Id. at 1 (quoting Grant Gilmore, The Ages of American Law 95 (1977)).

188. Id. at 149,164 .

189. Id. at 3. 
happening. " $[\mathrm{B}]$ ecause a statute is hard to revise once it is passed, laws are governing us that would not and could not be enacted today, and . . . some of these laws not only could not be reenacted but also do not fit, are in some sense inconsistent with, our whole legal landscape."190 Some remedy was needed: "To let the statute stand is frequently to perpetuate the will of a majority that no longer exists." 191

Calabresi proposed that courts take on the function of reviewing statutes, just as they reviewed common law precedent, to determine if they fit the "legal topography." 192 "What, then, is the common law function to be exercised by courts today?" he asked himself. He answered:

It is no more and no less than the critical task of deciding when a retentionist or a revisionist bias is appropriately applied to an existing statutory or common law rule. It is the judgmental function ... of deciding when a rule has come to be sufficiently out of phase with the whole legal framework so that, whatever its age, it can only stand if a current majoritarian or representative body reaffirms it. It is to be the allocator of that burden of inertia which our system of separation of powers and checks and balances mandates. It is to assign the task of overcoming inertia to that interest, whose desires do not conform with the fabric of the law, and hence whose wishes can only be recognized if current and clear majoritarian support exists for them. ${ }^{193}$

Calabresi's theory has been generously praised, and it has at the same time sparked significant criticism. It has been suggested that there may well be too few "obsolescent" statutes to warrant concern. ${ }^{194}$ Judicial assumption of this new function without explicit congressional authorization has been attacked as lacking in legitimacy, ${ }^{195}$ and it has been contended that Calabresi's system is unworkable. ${ }^{196}$ None of these criticisms touches on Calabresi's central insight-which was also Bickel's: In a democracy, rules established by a current majority have a better claim to legitimacy than rules established by an old majority.

Another criticism of Calabresi, however, deserves to be noted because it, unlike the others, applies to Bickel as well and should be considered in determining whether the Bickelian approach should be followed in the revival context. Critics charge Calabresi with failing to

190. Id. at 2 .

191. Id. at 109.

192. Id. at 18.

193. Id. at 164 .

194. $S \rightarrow$ Frank M. Coffin, The Problem of Obsolete Statutes: A New Role for Courts?, 91 Yale L.J. 827, 836 (1982) (reviewing Calabresi, supra note 151).

195. See Samuel Estreicher, Judicial Nullification: Guido Calabresi's Uncommon Law for a Statutory Age, 57 N.Y.U. L. Rev. 1126, 1136 (1982) (reviewing Calabresi, supra note 151 ).

196. See Coffin, supra note 194 , at $838-39$. 
acknowledge the importance of continuity in our governmental system. As Professor Farber wrote:

Our legislative process is designed so that laws will outlive the political coalitions that enact them. It is not at all clear that a democratic system could function otherwise. What is clear is that pure majoritarianism has never been our system of government. It is a basic institutional requirement of our system of government that the legitimacy of a statute be independent of the current state of public opinion. ${ }^{197}$

It is thus argued that Calabresi fails to accord adequate weight to the importance of inertia in our governmental system. "Without these constraints and constructs [that promote legislative inertia], legislatures would be plagued by instability and would be unable to function as deliberative bodies," 198 Farber wrote, and then added, "This is one of the fundamental insights of modern public choice theory." 199

In the next section, we will apply the Bickelian insights to the revival question and make the argument for nonrevival. We will also explain why the criticisms that have been leveled against Bickel's approach are irrelevant to our proposed solution of prospective overruling.

\section{B. Revival and Current Majoritarianism}

Bickel suggests that our primary concern should be with the decisions made by current legislators, rather than with the decisions made by those in the past. As a general matter, according to the Bickelian view, if legislators today fail to pass any legislation in an area of constitutional significance, then there should not be any legislation in that area in force. A strong form of this view would suggest that any legislation should expire after a relatively brief period of time. Bickel, however, stops short of this position. He argues that most statutes, because they are enforced, are subject to something akin to ongoing majoritarian review; the fact that the enforcement of a statute does not lead to its repeal suggests that the statute has a significant amount of support. It is only in the case of the unenforced statute that the judiciary should take steps to force legislative reconsideration.

It should be recognized that implicit in Bickel's argument is a bias against regulation. This bias, although somewhat obscured by his stress on current majoritarian decision-making, is a necessary premise of his argument. When legislative forces are deadlocked in a matter

197. Daniel A. Farber, Statutory Interpretation and Legislative Supremacy, 78 Geo. L.J. 281, 308-09 (1989).

198. Id. at 308 .

199. Id. at 308 n.140. For examples of works in public choice theory that stress the significance of stability in the legislative process, see William $\mathrm{H}$. Riker, Liberalism Against Populism 169-95 (1982); Daniel A. Farber \& Phillip P. Frickey, Legislative Intent and Public Choice, 74 Va. L. Rev. 423, 425-35 (1988). 
that raises constitutional concerns (without necessarily violating the Constitution), Bickel assumes that the appropriate legal response is to employ a default rule under which no law is in effect. Yet, if one presumes deadlock, one also presumes that neither the forces in favor of the old law nor those in favor of repealing the old law have the necessary support to shift the legal position from the position they oppose to the one that they desire. (Thus, the proponents of the statute could not secure its passage, if it were not on the books; its opponents could not secure its repeal, if it were already on the books). Neither enforcement or nonenforcement, then, can appropriately be considered the result of current majoritarian decision-making. Bickel's bias against regulation breaks the deadlock.

When the statute at issue imposes restraints on individual libertyeven if those restraints are not unconstitutional-Bickel's argument accords with the most fundamental tenets of constitutional governance. As the framers repeatedly made clear in the ratification debates, our federal government is one of limited powers. Those powers that the people did not delegate, they retained. It was precisely for this reason that many argued that a Bill of Rights was not necessary: in enacting the Constitution, the people were not delegating the power to encroach on individual liberty. Thus, Hamilton argued in Federalist 84 that bills of rights "according to their primitive signification ... have no application to constitutions, professedly founded upon the power of the people and executed by their immediate representatives and servants. Here, in strictness, the people surrender nothing; and as they retain everything they have no need of particular reservations." 200

Coupled with the libertarian bias of our constitutional system, this suggests that if a statute diminishes individual liberty it should be enforceable only if it is desired by a current majority. In this context, then, Bickel's default rule of no regulation makes sense. But when a challenged statute implicates other areas of constitutional governance the argument loses its cogency. Other than the political reliance concerns previously discussed and the individual reliance interests that the law has traditionally recognized, there is, for example, no obvious reason why with respect to a statute that is problematic on, say, separation of powers grounds, a default position of no statute is preferable to the default position established by the old statute.

Nonrevival of statutes implicating individual liberty directly follows from the Bickelian premises identified above. A statute that has been at one point at odds with governing decisions of constitutional law concerned with the protection of individual liberty interests should be enforceable only if it is desired by a current majority that has been

200. The Federalist No. 84, at 513 (Alexander Hamilton) (Clinton Rossiter ed. 1961). For the similar arguments of other Federalists, see Gordon S. Wood, The Creation of the American Republic: 1776-1787, at 539-41 (1969). 
informed by judicial decisions of the relevant constitutional parameters.

The Bickelian case for nonrevival is strongest when the statute has long been unenforced because of a judicial decision that held the statute unconstitutional or that announced a rule of law under which the statute was unconstitutional. Because of this passage of time, the parallel between such a fact pattern and that in Poe is strong. The primary factual difference between the two situations is the reason for nonenforcement, and that difference makes the case for nonrevival stronger than the case for passive virtues. With respect to the birth control statute in Poe, nonenforcement both manifested and contributed to political deadlock; deadlock was very clearly not the result of some prior judicial action. In the nonrevival context, however, for reasons presented in our discussion of political reliance, the initial judicial decision of unconstitutionality altered the majoritarian decision-making process in a way that diminished the likelihood of repeal. In other words, in $P o e$, the fact that the statute had not been repealed indicated deadlock; in a case in which a statute has been held unconstitutional, failure to repeal may not mean deadlock. In the nonrevival context, then, there is much less reason to find in the decisions of past majorities a surrogate for what a current majority would do, and there is therefore less reason to allow the decision of a past majority to establish the starting point for majoritarian decision-making. This argument concerning the appropriate starting point is particularly compelling when the past majority bears little resemblance to the current majority. ${ }^{201}$

The argument for nonrevival, however, is strong, even when the overruling decision follows shortly after the initial determination of unconstitutionality. For Bickel, the passive virtues represented devices that courts could use to force legislative reconsideration of statutes that they believed were problematic, but that they were unwilling to pronounce unconstitutional at that time. In the nonrevival situation, a majority of the court (although a past majority) once believed that the statute was not just problematic, but that it was unconstitutional. If courts and legislatures are to engage in constitutional dialogue, this is a situation in which it is particularly important for them to do so. Both the court decision holding a statute unconstitutional and the decision reversing the decision illuminate the constitutional concerns in an area. In other words, they apprise the legislature of what constitutional concerns are implicated by a statute. Only if the legislature knows of these concerns is it a fully informed constitutional actor, and only then should its actions be enforceable. Thus, Bickel's insights suggest that revival should never occur. Any statute that has been judicially invali-

201. The 1855 statute at issue in Weeks makes this point dramatically, since the electorate that selected the legislature that passed that statute excluded women and African-Americans. 
dated is thereby unenforceable for all time, although a second judicial decision reversing the first decision empowers the legislature to pass a statute identical to the one initially invalidated.

Bickel's work, therefore, suggests a second argument for extension of the doctrine of prospective overruling to the statutory context: prospective overruling is a device that courts can employ to remand to the legislature statutes that implicate individual liberty interests. ${ }^{202}$ In this view, the need to remand a statute justifies application of the technique of prospective overruling regardless of whether the case is one in which there has been political reliance.

The nature of the technique of prospective overruling establishes limits as to its uses. Prospective overruling does not permit a court to remand all constitutionally problematic statutes. It permits a court to remand only those statutes that are inconsistent with prior governing decisions of constitutional law. ${ }^{203}$

202. There may be instances in which there is a dispute about whether a statute implicates protected liberty interests. Assume, for example, a situation in which the invalidating decision concludes that a statute violates the right to privacy and the overruling decision finds that the Constitution does not protect a right to privacy. Supporters of the overruling decision might thus argue that the statute is not only constitutional, but that it does not even burden a cognizable liberty interest. Nonetheless, under the test set forth in this part, such a statute would not be revived because that statute was at one time inconsistent with governing case laws and because that case law was concerned with the protection of individual liberty interests. Such a result is appropriate for two reasons. First, the invalidating decision means that there has been significant support for the position that the statute is unconstitutional; such support weighs in favor of the result that the statute should be enforceable only if desired by a current majority. Second, the bright-line test used here sufficiently limits courts so they will be constrained in terms of which statutes they can force the legislature to reconsider; in other words, nonrevival in this limited category of cases (i.e., ones in which the overruling decision fails to recognize that a liberty interest is implicated) is consistent with our view that courts should be subject to significant constraints in their use of the technique of prospective overruling of statutes.

203. The way in which we are using Bickel's and Calabresi's work here should thus be contrasted with their previous invocation in the context of arguments against revival of abortion statutes. We are not simply suggesting that courts should simply be able to remand constitutionally problematic statutes for reconsideration. See NARAL Brief, supra note 58, at $31 \mathrm{n} .28$ (invoking Calabresi, Bickel, and others in support of notion of remanding). We are, rather, suggesting that concerns that these authors identified warrant the creation of a new judicial technique which will have a limited range of applications.

We are also not arguing for the use of desuetude or for that of a Calabresian second look doctrine. See Scott, supra note 58, at 381-88. As previously discussed, see supra notes 175-179, 194-199 and accompanying text, these techniques have been subject to telling criticism. Moreover, they do not address the problems associated with revival. A constitutionally problematic statute can still be consistent with the legal topography; thus, the Calabresian second look doctrine cannot force remanding in many situations in which it would be appropriate. Similarly, the doctrine of desuetude is inapplicable if the statute is recent or if, despite the fact that it is inconsistent with governing decisions of constitutional law, it has been consistently enforced (like the Washington State statute at issue in W'est Coast Hotel, see supra notes 29-31 and accompanying text). 
As has been pointed out, Bickel's passive virtues have been subject to substantial criticisms. But nonrevival of statutes through the use of the technique of prospective overruling-while it accords with Bickel's insights-is not subject to these criticisms.

Gunther correctly observed that, as Bickel championed the various passive virtues judicial techniques, he also altered their substance, and he did so without establishing principled limits to their use. Because Bickel redefined the passive virtues techniques in a way that left them unconstrained by precedential limits, he gave courts almost complete freedom to decide to force reconsideration of statutes.

Prospective overruling in the statutory context is, in contrast, a technique of limited application. It is of use only for a relatively small category of cases: those in which a finding of unconstitutionality is reversed. Prospective overruling in the statutory context, then, unlike Bickel's passive virtues, would not allow courts to provoke reconsideration of any statute that they found constitutionally troublesome. Indeed, with respect to prospective overruling, the question is not whether there is substantial support for the position that a particular statute is unconstitutional. Rather, prospective overruling in this context uses a simple bright line test: Is this statute one that was at one time inconsistent with governing case law, and was that case law based on protection of individual liberty interests?204

The other principal critique of current majoritarianism is the public choice critique that Farber advanced against Calabresi, but that is equally applicable to Bickel. Farber argued that our system of government is premised on the idea that legislation enacted under the auspices of temporarily assembled coalitions will be enforced. Political actors order their priorities in reliance on that fact, and to allow legislation that lacks current majoritarian support to expire would be to strip our governmental system of stability.

Again, this critique does not apply to the revival issue. The Calabresian and Bickelian models give judges permission to roam freely through the legal landscape, invalidating a wide range of laws. Revival arises in a limited number of situations, as the dearth of cases on point suggests. Thus, while the Calabresian and Bickelian models by their very breadth threaten the expectations of political actors and

204. Again, it should be made clear that this is a separate inquiry from the political reliance inquiry. If there is political reliance that meets the criteria set forth above (see supra text accompanying notes 141-149), prospective overruling is appropriate, even if the statute at issue does not implicate liberty interests.

One gloss, however, should be added to the rule stated in the text: When the court has already signalled its willingness to reexamine the invalidating decision-the Baker case in the typology previously mentioned-and a statute inconsistent with the invalidating decision is passed, there is no need for prospective overruling of that statute if the invalidating decision is reversed: informed by the initial invalidating decision, the legislature has nonetheless decided that it wants the statute, and it has done so at a time in which the political process is not skewed by reliance on judicial decisions. 
could cause an underinvestment of efforts in political movements, revival does not raise that issue.

Moreover, as our discussion of political reliance shows, while the Bickelian and Calabresian models undermine the inertial quality of our governmental system, nonrevival reinforces it. In other words, the Bickelian and Calabresian models tell political actors that they cannot allocate resources in reliance on the law as currently reflected in the body of statutes that the courts have not stricken. Thus, if Bickel's approach had been followed, birth control opponents in Connecticut would not have been able to rely on the existence of a statute as sufficient protection of their position; they would also have had to allocate their resources to securing enforcement, even though they were satisfied with the status quo. Under nonrevival, however, political actors can rely on judicial invalidation of a statute as a bar to future enforcement of that statute and structure their political activities accordingly. There is no uncertainty, no misallocation of resources.

Nonetheless, it should be recognized that prospective overruling in cases involving constitutionally problematic statutes is less consistent with precedent than prospective overruling designed to protect political reliance. Prospective overruling to protect political reliance is similar to well-established techniques that courts use to protect those who rely on judicial pronouncements. There is, in contrast, only a small body of opinions that can be used to support the notion that courts remand constitutionally problematic statutes for reconsideration, ${ }^{205}$ and similarly, there is no well-established analogue to a technique that would allow courts to evaluate constitutionally problematic statutes under the rule of the invalidating decision, rather than under the rule of the subsequent overruling decision.

Thus, the strength of the argument for use of the doctrine of prospective overruling in evaluating constitutionally problematic statutes rests on first principles. Since the criticisms of Bickel and Calabresi do not provide bases for rejecting nonrevival through prospective overruling, the choice between revival and nonrevival is reduced to a choice between two different majoritarian approaches. Should courts adopt the revival position and enforce the decisions of past majorities-decisions uninformed by evolving constitutional doctrine-when those decisions affect individual liberty? Or should they, in accordance with the nonrevival position, leave the matter to the resolution of current majorities, informed by the relevant judicial decisions? As Bickel's writings demonstrate, the latter option is the one that is consistent with our constitutional system's commitment to the promotion of liberty.

\section{Conclusion}

People rely on the finality of judicial decisions. Over seventy years 
ago, Benjamin Cardozo argued that courts should be free to protect that reliance interest by overruling their prior decisions prospectively and not applying a new rule of law to transactions that predated its announcement. ${ }^{206}$ In this Article, we have argued that that logic is equally applicable to the political context. When courts overrule a prior decision, they should be able to judge statutes passed before the new decision under the constitutional principles that had been in place prior to the overruling decision. Prospective overruling with respect to statutes is at odds with much of the limited body of relevant cases and commentary, which has been premised on the notion that revival of statutes that have been "unconstitutional" under previous case law merely implements the majoritarian will. This premise, however, fails to take into account the way in which a judicial determination of unconstitutionality alters the political process. Revival can produce a counter-majoritarian result and harm those political actors who have relied on the court's initial judgment.

Use of prospective overruling is also appropriate when there has been governing case law under which a statute, or one substantially similar to it, was held to violate an individual liberty right protected by the Constitution. When that governing case law is overturned, the statute should have to be repassed before it can be enforceable; statutes that implicate individual liberty interests should be enforced only if the current majority supports them.

206. See supra note 98 and accompanying text. 